\title{
Epigenetics and Immunometabolism in Diabetes and Aging
}

\author{
Tomasz J. Guzik ${ }^{1,2}$ and Francesco Cosentino ${ }^{3}$
}

\begin{abstract}
Significance: A strong relationship between hyperglycemia, impaired insulin pathway, and cardiovascular disease in type 2 diabetes (T2D) is linked to oxidative stress and inflammation. Immunometabolic pathways link these pathogenic processes and pose important potential therapeutic targets.

Recent Advances: The link between immunity and metabolism is bidirectional and includes the role of inflammation in the pathogenesis of metabolic disorders such as T2D, obesity, metabolic syndrome, and hypertension and the role of metabolic factors in regulation of immune cell functions. Low-grade inflammation, oxidative stress, balance between superoxide and nitric oxide, and the infiltration of macrophages, $\mathrm{T}$ cells, and $\mathrm{B}$ cells in insulin-sensitive tissues lead to metabolic impairment and accelerated aging.

Critical Issues: Inflammatory infiltrate and altered immune cell phenotype precede development of metabolic disorders. Inflammatory changes are tightly linked to alterations in metabolic status and energy expenditure and are controlled by epigenetic mechanisms.

Future Directions: A better comprehension of these mechanistic insights is of utmost importance to identify novel molecular targets. In this study, we describe a complex scenario of epigenetic changes and immunometabolism linking to diabetes and aging-associated vascular disease. Antioxid. Redox Signal. 29, 257-274.
\end{abstract}

Keywords: vascular, inflammation, epigenetics, nitric oxide, superoxide, diabetes

\section{Introduction}

$\mathbf{T}$ HE PREVALENCE OF OBESITY and type 2 diabetes (T2D) mellitus is alarmingly increasing worldwide $(12,71)$. The International Diabetes Federation currently estimates that 415 million people have been diagnosed with diabetes mellitus worldwide and anticipate an increase up to 640 million by the year 2040 (1). The main determinants of this increase are represented by modifiable (sedentary lifestyle and dietary habits) and nonmodifiable factors (genetic predisposition and aging; 119). T2D is associated with increased risk of micro- and macrovascular complications and approximately twofold greater mortality when compared with the general population (71). Advances in therapy have reduced T2D morbidity and mortality. However, cardiovas- cular risk is far to be eradicated, and mechanism-based therapeutic approaches are needed (42). In patients with T2D, high glucose levels trigger endothelial inflammation, mitochondrial oxidative stress, and reduced availability of nitric oxide (NO), all contributing to cardiovascular complications. One of the key predictive factors related to microand macroangiopathy is associated with accelerated vascular aging resulting in atherosclerosis and microvascular dysfunction $(9,144)$. Low-grade inflammation has been established as one of the key mechanisms linking these conditions $(51,97,98,113,138)$. Therefore, T2D is a prime example of an interplay between metabolism and immunity, making it prototypic for an in-depth look into immunometabolism. It has been known since the 1980s that insulin and insulin receptors modulate immunity (64). At the same time,

\footnotetext{
${ }^{1}$ BHF Centre for Research Excellence, Institute of Cardiovascular and Medical Research (ICAMS), University of Glasgow, Glasgow, United Kingdom.

${ }^{2}$ Department of Internal and Agricultural Medicine, Laboratory of Translational Medicine, Jagiellonian University Collegium Medicum, Krakow, Poland.

${ }^{3}$ Cardiology Unit, Department of Medicine, Karolinska Institute, Karolinska University Hospital, Stockholm, Sweden.

(C) Tomasz J. Guzik and Francesco Cosentino, 2017; Published by Mary Ann Liebert, Inc. This Open Access article is distributed under the terms of the Creative Commons License (http://creativecommons.org/licenses/by/4.0), which permits unrestricted use, distribution, and reproduction in any medium, provided the original work is properly cited.
} 
low-grade inflammation and the infiltration of immune cells into insulin-sensitive tissues lead to metabolic impairment and accelerated aging (145). Perivascular and adipose tissue (AT) inflammatory infiltrate, and altered immune cell phenotype, can precede the development of metabolic disorders, including obesity, insulin resistance, T2D, atherosclerosis $(129,150)$, or hypertension (102). Moreover, specific ablation of macrophages, B cells, or T cells from the AT can not only restore metabolic function but also prevent development of related pathologies $(51,145)$. Clinical significance is emphasized by the prognostic value of C-reactive protein levels or plasma cytokines such as interleukin (IL)-6 or tumor necrosis factor alpha (TNF- $\alpha$; 74), although ongoing clinical trials will give us strong insight soon. Better understanding of immunometabolic diseases may lead to the development of novel immune targeted therapies in the treatment and prevention of metabolic dysfunction in hypertension, diabetes, and aging. Epigenetic mechanisms that control immune cell lineage determination, function, and migration are implicated (132, 149) and can provide valuable therapeutic targets in the future.

Epigenetic modifications are emerging as key players in the setting of this pathogenetic chain of events (61). Acetylation and methylation at DNA/histone complexes significantly alter gene expression by modulating chromatin accessibility (21).

\section{Accelerated Vascular Aging in Diabetes}

Accelerated vascular aging is characterized by progressive pathological vascular remodeling, dependent on vascular fibrosis and calcification, leading to vascular stiffening as a clinical manifestation and is particularly prevalent in T2D (Fig. 1) (172). It bears important prognostic significance (40). Extracellular matrix remodeling is initiated by risk factors such as hypertension and diabetes and is mediated by endothelial dysfunction and vascular inflammation (28). Factors affecting collagen deposition and matrix degradation are linked to pathologic vascular remodeling also in the context of inflammation $(25,92)$. MMP9 (metalloproteinase 9) is, for example, essential for driving macrophage-dependent inflammation in the context of aging (92), although the cause-effect relationship between matrix remodeling factors and cardiovascular outcomes remains poorly defined (31), and may indicate other important regulators. Telomere shortening is one of the features of accelerated vascular aging. Indeed, vascular telomere length is lower in T2D patients (162). This is also important as a recent cross-sectional study demonstrated that telomere length is independently associated with subclinical atherosclerosis in subjects with T2D (152). However, accelerated telomere attrition was recently reported in circulating leukocytes, but not arteries, in T2D compared to control rats (156). This indicates the importance of immune senescence in diabetic vascular dysfunction/aging pathogenesis and that leukocytes may be primary targets of accelerated aging.

\section{Immunometabolism: Basic Concepts}

The relationship between immunity and metabolism is bidirectional and includes (i) the role of inflammation in the pathogenesis of metabolic disorders, such as diabetes, obesity, metabolic syndrome, and hypertension and (ii) the role of metabolic factors in regulation of immune cell functions (132). The latter encompasses the effects of metabolic state of the environment on inflammation and the metabolic processes within the immune cells that regulate immunity (112).

It has been well recognized that metabolic state of environment may affect the development of inflammation (11, 87) particularly by affecting substrates available and also by changing chemokine gradients and local cytokine production. Overabundance of substrates observed in obesity and metabolic syndrome affects the phenotype of both infiltrating and resident immune cells (145). This has been strongly demonstrated in relation to macrophage phenotype switching between M1 and M2 (190).

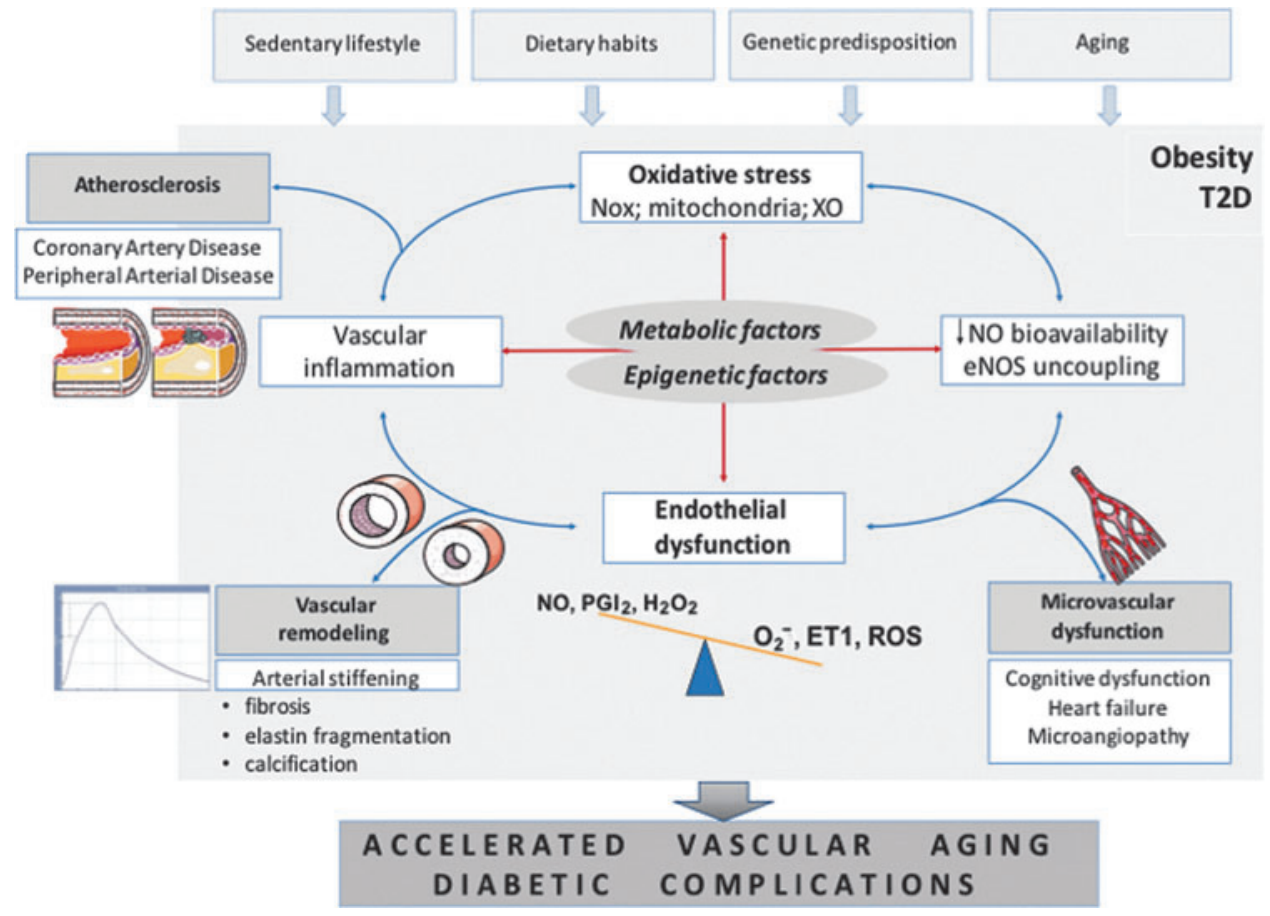

FIG. 1. Vicious cycle of oxidative stress, endothelial dysfunction, and vascular inflammation in the pathogenesis of vascular complications of metabolic disorders. eNOS, endothelial nitric oxide synthase; ET1, endothelin 1; $\mathrm{H}_{2} \mathrm{O}_{2}$, hydrogen peroxide; NO, nitric oxide; Nox, nonphagocytic NADPH oxidase; $\mathrm{O}_{2}{ }^{-}$, superoxide anion; $\mathrm{PGI}_{2}$, prostacyclin; ROS, reactive oxygen species; T2D, type 2 diabetes; XO, xanthine oxidase. 


\section{Macrophages}

More importantly, however, immune responses are accompanied by a dramatic metabolic switch within the immune cells themselves (145). For example, interferon gamma (IFN$\gamma$ )-activated (M1 type) macrophages rapidly shift to aerobic glycolysis, while M2-type macrophages rely on oxidative phosphorylation (Fig. 2). This has been first identified nearly five decades ago in studies of peritoneal macrophages demonstrating their increased glycolysis and decreased oxygen consumption on activation (62).

\section{T cells}

Similar metabolic switches are related to adaptive $\mathrm{T}$ cell responses. Naive and quiescent $\mathrm{T}$ cells rely on glucose and fatty acid metabolism for energy, such as the tricarboxylic acid cycle, linked to the generation of adenosine triphosphate (ATP) via oxidative phosphorylation (Fig. 2; Table 1; 36, 125). When antigen is presented during immune challenge, T lymphocytes engage pathways of anabolic metabolism, switching to aerobic glycolysis (regulated greatly by mechanistic target of rapamycin or mTOR), to support clonal expansion and the development of effector functions (Fig. 2; Table 1; 107). $\mathrm{T}$ regulatory cells (Treg) are, in turn, dependent on oxidative phosphorylation and lipid peroxidation $(93,101)$. T cell activation is associated with transient activation of AMP-activated protein kinase (AMPK), a sensor of cellular energy levels, which allows the cells to prepare for high-energy consuming processes that follow $\mathrm{T}$ cell receptor activation (157).

\section{Glucose metabolism and immune activation}

The metabolic changes within the $\mathrm{T}$ cell during activation are modulated by environmental factors, such as insulin, which promotes $\mathrm{T}$ cell activation (64). Classical $\mathrm{T}$ cell activation is accompanied by upregulation of the insulin recep- tor, with subsequent increase in Glut1, Glut3, and Glut4, as well as an upregulation of glycolytic enzymes (37). These events are required for efficient adaptive immunity. Silencing the insulin receptor impairs $\mathrm{T}$ cell functions related to glucose transport and glycolysis, including polyclonal activation of CD4+ T cells, effector cytokine (Th1 type-IFN- $\gamma$ and TNF and Th17 type-IL-17) production, migration, and proliferation (37). This was associated with alterations in intracellular signaling pathways, including RAS/ERK, PI3K/AKT, and mTOR pathways (37). The cytotoxicity of CD8+ T cells in response to alloantigens is also dependent on insulin receptor (37). Moreover, recent evidence suggests that regulatory $\mathrm{T}$ cells (Tregs) express the insulin receptor, and that high levels of insulin impair the ability of Tregs to suppress inflammatory responses via effects on the AKT/mTOR signaling pathway (60). The effect of insulin on Treg suppression is limited to IL-10 production and does not alter other suppression mechanisms.

Apart from the key role of mTOR in regulation of immune cell metabolism, particularly interesting data are related to the role of AMPK. AMPK is not only an important sensor of the cellular energy levels but through its potential inhibition by metformin may represent a potentially important pharmacological target for modulation of immunometabolism as well (5). Metformin, an activator of AMPK, inhibits Th1 and Th17 cell differentiation (76), while enhancing Treg through metabolic effects on fatty acid oxidation and glycolysis, leading to anti-inflammatory effects in vivo (151). This role of AMPK also provides a link between immunometabolism and oxidative stress.

\section{Therapeutic implications of immunometabolism}

One of the key concepts of immunometabolism is related to the fact that immune cells can be reprogrammed by interfering with their metabolic states. This creates a possible
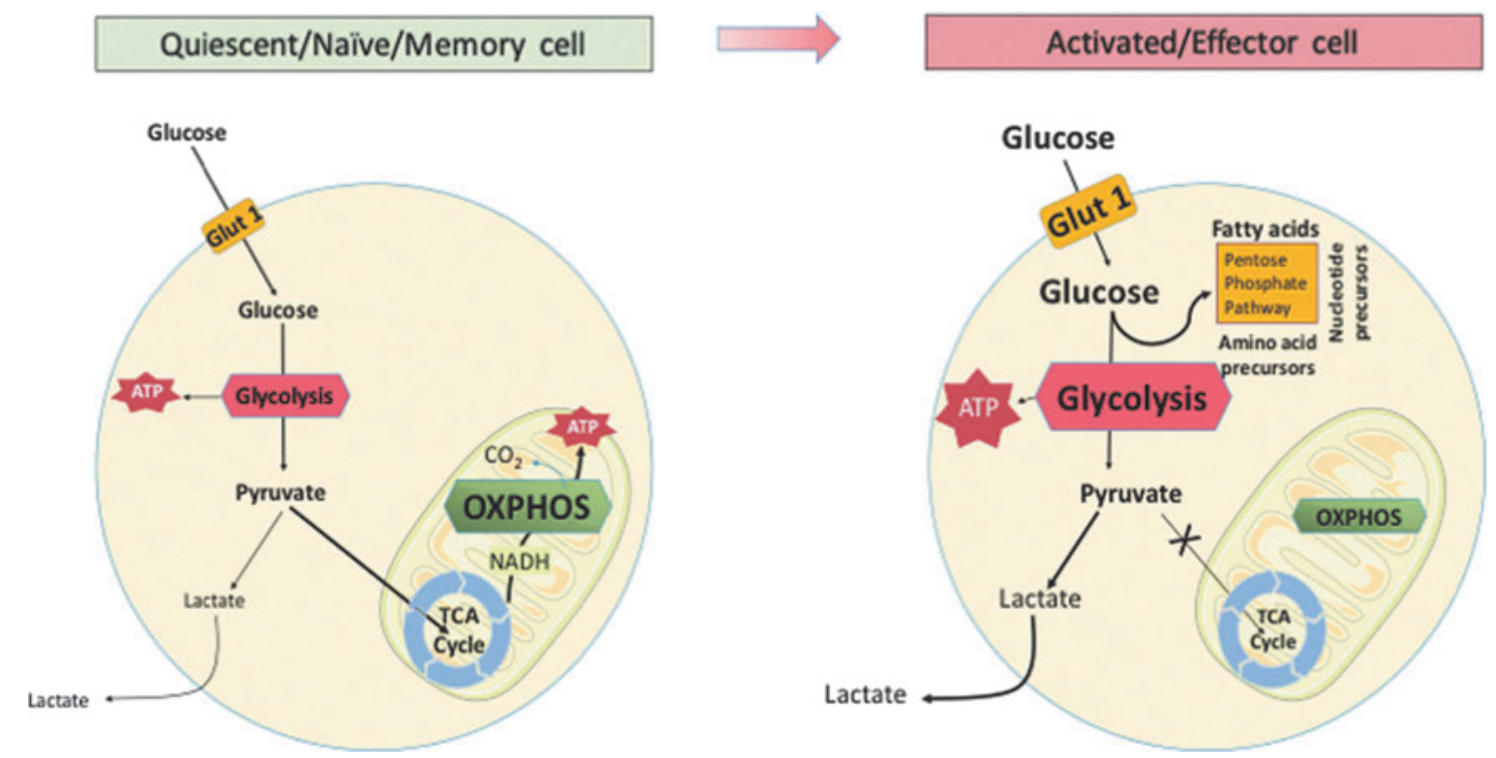

FIG. 2. Schematic representation of metabolic alterations between OXPHOS and anaerobic glycolysis is one of the key determinants of immune cell activation (e.g., macrophage or $\mathbf{T}$ cell) from quiescent state. Modified, based on (36) TCA/Krebs cycle; ATP; Modified from ATP, adenosine triphosphate; OXPHOS, oxidative phosphorylation; TCA, tricarboxylic acid. 
Table 1. Major Immune Cell Populations Infiltrating Adipose Tissue, Their Role in Insulin Resistance, Key Effector Mechanisms, and Metabolic Regulation of Their Function

\begin{tabular}{|c|c|c|c|c|}
\hline Cell type & $\begin{array}{c}\text { Effect on } \\
\text { insulin resistance }\end{array}$ & Key effector mechanisms & Metabolic program & $\begin{array}{l}\text { Key metabolic } \\
\text { regulator }\end{array}$ \\
\hline \multicolumn{5}{|l|}{ Myeloid cells } \\
\hline M1 Mf & $\Uparrow$ & TNF; IL-6; iNOS & Aerobic glycolysis & $\begin{array}{l}\text { mTOR/HIF1f/Glut } \\
\text { PFK2 }\end{array}$ \\
\hline M2 Mf & $\Downarrow$ & IL-10; arginase & Oxidative phosphorylation & AMPK; STAT6 \\
\hline Dendritic cells & $\Uparrow$ & IL-12; IL-15 & $\begin{array}{l}\text { Aerobic glycolysis } \\
\text { (in activated state) }\end{array}$ & mTORC1; mTORC2 \\
\hline Mast cells & $\Uparrow$ & Histamine; PGE2; TNF & $\begin{array}{l}\text { Aerobic glycolysis and } \\
\text { oxidative phosphorylation }\end{array}$ & mTOR? AMPK \\
\hline Neutrophils & $\Uparrow$ & MPO; IL-8; IL-1b; NETs & Glycolytic & mTORC1 \\
\hline Eosinophils & $\Downarrow$ & IL-10; IL-13; TGFb; IL-13 & Glycolytic & AMPK \\
\hline \multicolumn{5}{|l|}{ Lymphoid cells } \\
\hline Naive T cells & & & $\begin{array}{l}\text { Mixed fuel oxidative } \\
\text { phosphorylation }\end{array}$ & \\
\hline $\begin{array}{l}\text { Effector T cells } \\
\mathrm{T} \text { h cells }(\mathrm{CD} 4+)\end{array}$ & & & Aerobic glycolysis & \\
\hline Th1 & $\Uparrow$ & IFN- $\gamma ;$ Tbx 21 & Aerobic glycolysis & mTORC1 \\
\hline Th2 & $\Downarrow$ & IL-4; IL-5; IL-13 & Aerobic glycolysis & mTORC1; mTORC2 \\
\hline Th17 & $\Uparrow$ & IL-17 & Aerobic glycolysis & mTORC1; HIF-1a \\
\hline Treg (FOXP3+) & $\Downarrow$ & IL-10; TGFb & Lipid oxidation & AMPK \\
\hline $\mathrm{T} \mathrm{c}(\mathrm{CD} 8+)$ & $\Uparrow$ & $\begin{array}{l}\text { TNF; IFN- } \gamma \\
\text { (perforin/granzyme) }\end{array}$ & Aerobic glycolysis & mTORC1 \\
\hline Memory $T$ cells & & & Lipid oxidation & TRAF6; AMPK \\
\hline NK cells & $\Uparrow$ & TNFa; IFN- $\gamma ;$ IL4; IL13 & Aerobic glycolysis & (mTORC1) \\
\hline $\mathrm{B}$ cells & $\Uparrow$ & $\operatorname{IgG}$ & ? & $?$ \\
\hline
\end{tabular}

For detailed discussion and references see text $(5,37,60,64,96,105,113,131,154,166)$.

AMPK, AMP-activated protein kinase; IFN- $\gamma$, interferon gamma; IgG, immunoglobulin G; IL, interleukin; iNOS, inducible nitric oxide synthase; M1/M2, types of macrophages; Mf, macrophage; mTOR, mechanistic target of rapamycin; TNF, tumor necrosis factor; TRAF, TNF receptor-associated factor.

therapeutic utility. M2 macrophage profile is promoted on inhibition of glycolysis (e.g., by inhibiting pyruvate kinase M2; 116). Similarly, proinflammatory IL-17 producing $\mathrm{T}$ cells can be reprogrammed to develop into Treg-like cytokine producing profile by inhibition of glycolysis (e.g., using 2-deoxyglucose).

\section{Immunometabolism of Diabetes}

Accumulating evidence suggests that development of vascular complications of diabetes is dependent on interactions between immune cells and vascular wall components $(70,141)$. Indeed, immune cell infiltration is a key feature linking obesity to diabetes, as proinflammatory cytokines, macrophages, and $\mathrm{T}$ cells are essential for the development of insulin resistance (110). Both innate immunity and adaptive immunity contribute to metabolic pathology. A classical example is that the activation of toll-like receptors, IL-1 receptor type I or TNF receptor, results in nuclear factor kappa $\mathrm{B}(\mathrm{NF}-\kappa \mathrm{B})$ and Jun amino-terminal kinase signaling, leading to insulin receptor substrate (IRS)-1 and IRS-2 serine phosphorylation causing insulin resistance (112). Recognition of "metabolic" danger signals (such as glucose, ATP, or cholesterol) by the nucleotide oligomerization domain (NOD)like receptor (NLR) family leads to activation of the NLR pyrin domain-containing 3 (NLRP3) inflammasome. This results in M1 macrophage activation (164). Abundance of fatty acids in obesity promotes AT inflammation in a tolllike receptor 4 (TLR4)-dependent manner (147). In healthy, nonobese individuals, Th2 and Treg residing in the fat have a beneficial effect by reducing visceral adipose tissue (VAT) inflammation. During obesity and other metabolic challenges, these cells are overwhelmed by proinflammatory CD8+ cells and Th1 CD4+ cells, which promote insulin resistance and glucose intolerance (174). CD4+ T cells have been recognized as a central regulator of chronic VAT inflammation, as they can modulate macrophage- and other $\mathrm{T}$ and $\mathrm{B}$ cell-dependent inflammatory responses. For example, IFN- $\gamma$-producing Th1 cells enhance proinflammatory macrophage activation in the AT, and IL-17 produced by Th17 cells may impair insulin receptor signaling in macrophages in culture and in surrounding AT (160). Th2 cells secreting IL-4 and IL-13 as well as the FOXP3+ Treg induce, in turn, antiinflammatory macrophages that release IL-10, inhibiting lowgrade inflammation in VAT $(35,105)$. Further characterization of AT infiltrating $\mathrm{T}$ cells in obesity revealed that they represent features of senescence-associated T cells typically seen in aging in the secondary immune organs. They promote chronic VAT inflammation and metabolic disorders by secreting large amounts of osteopontin (148). These CD153+PD$1+\mathrm{CD} 44$ hiCD4+ $\mathrm{T}$ cells are remarkably increased and preferentially accumulated in the VAT of high-fat diet-fed mice in a B cell-dependent manner. Indeed, B cells are critical for the pathogenesis of insulin resistance and metabolic dysfunction (173). Treatment with a clinically available anti-CD20 antibody, which results in significant reductions of B cells, attenuates disease. In contrast, transfer of immunoglobulins $G$ (IgGs) from obese mice to controls leads to the development of 
insulin resistance (173). B cells worsen glucose tolerance, in part, by inducing proinflammatory cytokine production by $\mathrm{T}$ lymphocytes. Less evidence is available in the clinical setting, but insulin resistance in obese humans has been shown to be linked to elevated IgG autoantibodies (173) and immune cell accumulation in VAT, in particular, activated CD4+ and CD8+ T cells (177).

While immune cells can promote insulin resistance and $\mathrm{T} 2 \mathrm{D}$, hyperinsulinemia, as previouly discussed, alters immunity by promoting $\mathrm{T}$ cell activation as well as it increases $\mathrm{T}$ cell glucose uptake, amino-acid transport, and lipid metabolism (64). These changes promote overall decrease in IL10 production with a parallel increase in production of IFN- $\gamma$, thus promoting a prodiabetic inflammatory milieu (60).

\section{Immunometabolic Determinants of Vascular Dysfunction in T2D}

While AT inflammation is essential for the development of insulin resistance, diabetes is associated with perivascular adipose tissue (PVAT) inflammation, which leads to macrovascular and microvascular complications. We have recently shown that macrophage, $\mathrm{T}$ cell, and dendritic cell infiltration into PVAT precedes development of large vessel endothelial dysfunction and oxidative stress (129, 150). Molecular mechanisms of PVAT inflammation include signal transducer and activator transcription 4 (STAT4) in adipocytes and immune cells. STAT4 deficiency reduces development of atherosclerosis and PVAT inflammation in apolipoprotein E $(\mathrm{ApoE})^{-/-}$mouse (26) and in insulin-resistant obese Zucker rats (126). The immune dysfunction linking diabetes to vascular disease includes $\mathrm{T}$ effector cell memory polarization (6) and monocyte subset changes toward proinflammatory monocytes $(103,161,171)$. PVAT inflammation is mediated by chemokines such as MCP-1 (monocyte chemoattractant protein 1), RANTES (regulated on activation, normal $\mathrm{T}$ cell expressed and secreted), or IP-10 (CXCL10) that recruit activated monocytes/macrophages and CD8+ T cells to PVAT $(51,54,70,113)$. Infiltrating cells release cytokines such as IFN- $\gamma$, TNF- $\alpha$, or IL- 6 , which induce insulin resistance $(19,90$, 91) and impair endothelium-dependent relaxation (82, 102, 103). IL-6 is also necessary for Th17 cell differentiation (14), another $\mathrm{T}$ cell subpopulation with strong proinflammatory impact on endothelial cells (ECs) and vascular smooth muscle cells (VSMCs) through activation of RhoA/Rho-kinase. It increases inhibitory endothelial nitric oxide synthase (eNOS) Thr495 phosphorylation in ECs leading to decreased NO production (108). Inflammatory cytokines modulate smooth muscle cell constriction, proliferation, and migration (99). They also affect adipokine release. For example, TNF, IL-6, and IL-17A can all inhibit expression of adiponectin or omentin-1, the vasoprotective adipokines $(33,69,84,170)$, and stimulate proinflammatory leptin and resistin $(84,111)$. Leptin, through its structural similarity to the cytokines of the longchain helical family such as IL-6, IL-12, and IL-15, can affect leukocyte activation, chemotaxis, and release of oxygen radicals. In vascular cells, it induces proliferation of VSMCs and expression of adhesion molecules on ECs and VSMCs (84). These aspects have been reviewed by us in detail elsewhere (58, 113). It can also directly induce vascular dysfunction and oxidative stress $(53,57,113)$ through possible effects on VSMC contractile function (176) and endothelial NO production.

\section{PVAT and Vascular Dysfunction}

While classically it is recognized that PVAT-derived adipokines and inflammatory cytokines affect EC and VSMC function, studies of human vascular dysfunction associated with metabolic impairment have led to a novel concept of an inside-to-outside signaling (Fig. 3; 7, 8, 96). According to this concept, bioactive compounds released from the vessel or the heart in conditions of increased oxidative stress can
FIG. 3. Interactions between PVAT and vascular wall components "outside to inside" and "inside to outside" theory of interactions in development of vascular pathologies. Both types of inteactions coexist in development of vascular dysfunction and augment each other. EC, endothelial cell; IFN- $\gamma$, interferon gamma; IgG, immunoglobulin $\mathrm{G}$; IL, interleukin; PPAR- $\gamma$, peroxisome proliferatoractivated receptor gamma; PVAT, perivascular adipose tissue; TNF- $\alpha$, tumor necrosis factor alpha; VSMC, vascular smooth muscle cell.

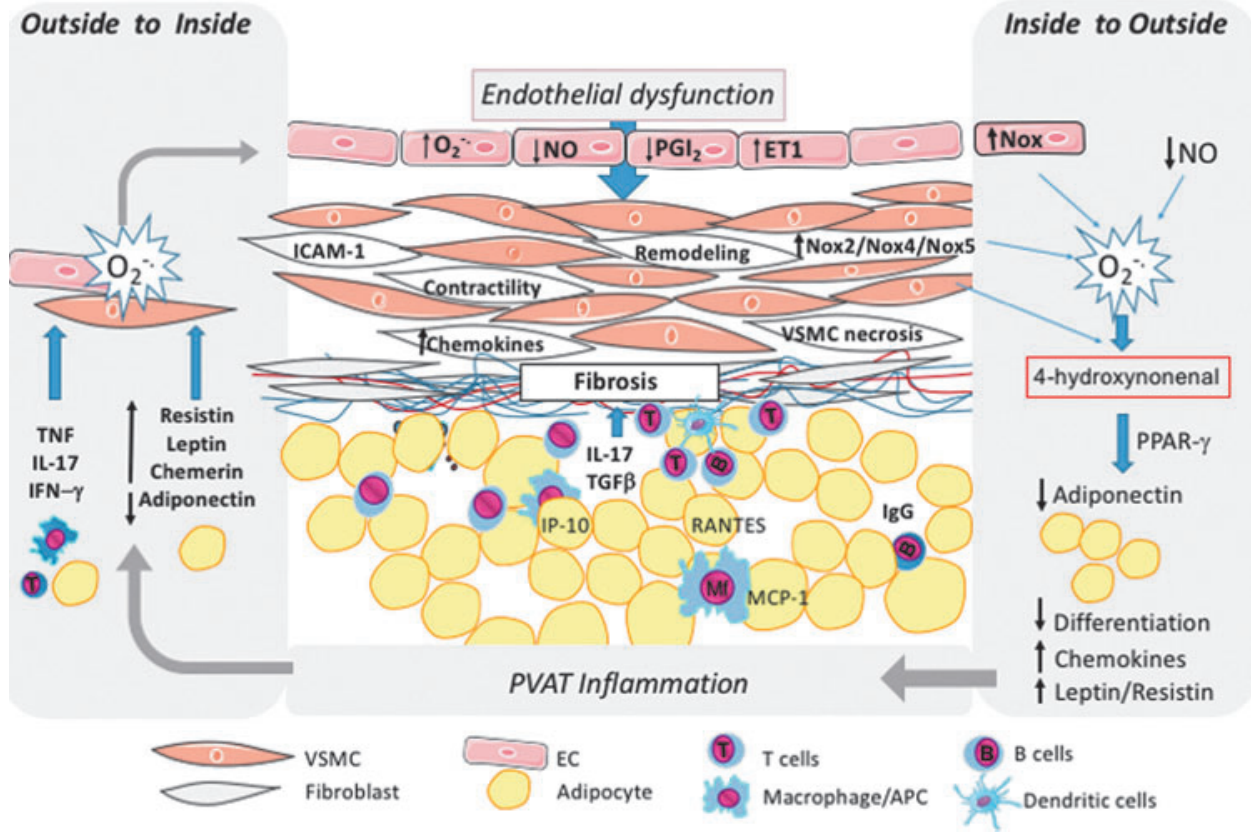




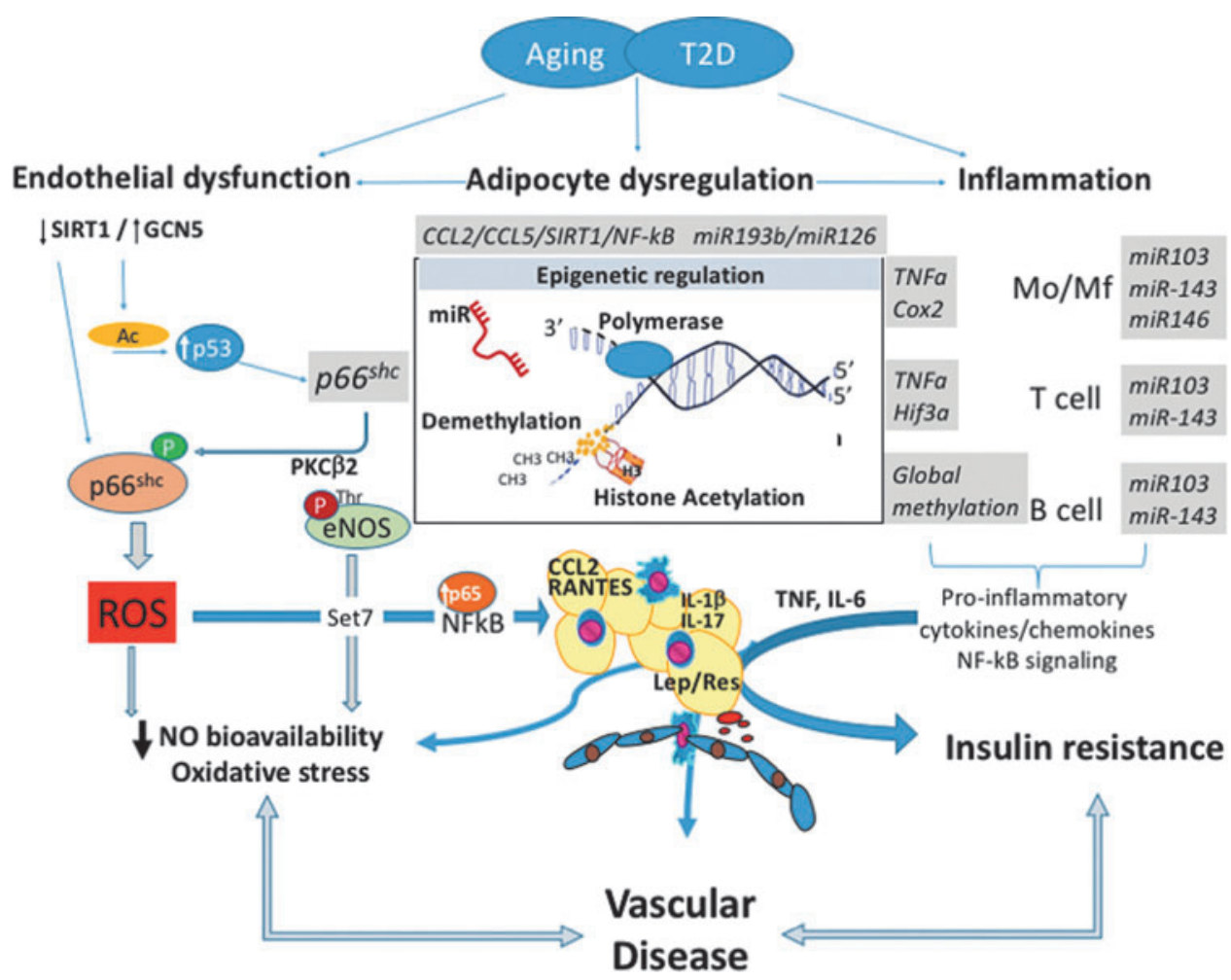

FIG. 4. Central role of epigenetic regulation in the pathogenesis of diabetic vascular dysfunction. Epigenetic changes within endothelium, adipocytes, in particular PVAT and inflammatory cells are all contributing to vascular dysfunction and metabolic dysregulation, including insulin resistance. Key genes identified to be regulated epigenetically in each of the discussed organ systems are indicated in gray along with miRNAs implicated. These epigenetic changes lead to oxidative stress, adipocyte and perivascular inflammation, and endothelial dysfunction. CCL, CC chemokine ligand; miRNAs, microRNAs; NF- $\kappa \mathrm{B}$, nuclear factor kappa B. reciprocally control the biosynthetic activity of the neighboring perivascular or epicardial AT $(7,8,96)$. While the mediators of this bidirectional cross talk are not clear, peroxidation products such as 4-hydroxynonenal that modulate gene expression within the PVAT or epicardial fat via PPAR- $\gamma$ dependent mechanisms have been shown $(7,8,96)$. This may constitute an important mechanism through which endothelial dysfunction and oxidative stress can affect metabolism of surrounding AT. VSMCs also regulate PVAT inflammation by releasing chemotactic factors and contributing to immune cell recruitment and activation. Strong evidence implicates metabolic regulation of VSMC controlled inflammation (130). Indoleamine 2,3-dioxygenase, the first rate-limiting enzyme of the kynurenine pathway of tryptophan (Trp) degradation, has immune regulation and anti-inflammatory mechanisms in vascular inflammation and, mainly through effects on Treg function, regulates vascular cell adhesion molecule (VCAM)-1 expression and vascular recruitment of macrophages in mice. Such effect can be reversed by exogenous administration of the Trp metabolite 3-hydroxyanthranilic acid (130). Response of immune cells to VSMC-derived danger signals is also tightly regulated. For example, the innate immune protein CARD9 in macrophages may mediate necrotic smooth muscle cellinduced inflammation by activating NF- $\kappa \mathrm{B}$ and contribute to neointima formation in vascular remodeling (89).

Finally, lymphatic vessel dysfunction is an emerging component of metabolic diseases (4). Lymphatics regulate tissue lipid accumulation, dyslipidemia, and edema. A recent study has demonstrated lymphatic dysfunction in diabetic $\mathrm{db} / \mathrm{db}$ mice, which was rescued by L-arginine (140). These authors also demonstrated that PDE3 (phosphodiesterase 3) inhibition is required to maintain lymphatic vessel integrity and represents a viable therapeutic target for lymphatic endothelial dysfunction in metabolic disease (140).
Thus, over the years it became apparent that vascular dysfunction associated with diabetes is closely regulated by coincident immune and metabolic dysregulation making immunometabolic interventions a valuable therapeutic approach in the prevention and treatment of diabetic vascular disease.

\section{The Role of Epigenetics in Immunometabolic Regulation}

The concept that adverse chromatin remodeling contributes to the pathogenesis of vascular damage in T2D has been introduced (78). Epigenetics is an important modulator of gene expression without affecting DNA sequence (26). Epigenetics leads to heritable changes in phenotype (61). The major mechanisms of epigenetic regulation are represented by DNA methylation, posttranslational histone modifications, and RNA regulating molecules such as noncoding RNAs (Fig. 4).

\section{Histone methylation and demethylation}

DNA methylation can inhibit gene transcription through the covalent attachment of a methyl group to cytosine residues in $\mathrm{CpG}$ islands (79). In the setting of diabetes, promoter hypomethylation leads to increased expression of genes involved in inflammation, adiposity, $\beta$ cell dysfunction, and vascular damage (88). Excessive free radical production is a major player for the onset of endothelial damage and impaired functionality. A better understanding of epigenetic changes affecting oxidant genes may unmask new mechanistic perspectives. Pathological chromatin remodeling causes gene expression changes that persist even after control of cardiovascular risk factors. Hypomethylation of the oxidant gene p66 $6^{\text {Shc }}$ is contributing to the hyperglycemic memory in experimental diabetes (121). Indeed, high glucose-exposed ECs 
(human) and T2D mouse aortas show $\mathrm{p} 66^{\mathrm{Shc}}$ overexpression after restoration to normal glucose levels (121). p66 ${ }^{\text {shc }}$ upregulation and mitochondrial translocation induced free radical generation and impaired NO release. Global methylation status of leukocytes and B cells has been associated with insulin resistance and T2D $(149,187)$. Specific methylation changes were observed in TNF- $\alpha$ (65), ubiquitin-associated and $\mathrm{SH} 3$ domain-containing protein $\mathrm{B}(U B A S H 3 B)$, or tripartite motifcontaining 3 (TRIM3) genes involved in immune regulation (169). DNA methyltransferase DNMT3B is increased in macrophages exposed to high levels of saturated fatty acids, promoting M1 polarization in turn (181). Aberrant promoter DNA methylation also results in pathological endothelial-tomesenchymal transition (EndMT) and subsequent fibrosis (179). Perivascular inflammation in turn is greatly orchestrated by RANTES receptor $C C R 5$ (CC chemokine 5 receptor) gene methylation (102).

\section{Histone acetylation and deacetylation}

Histone acetylation mark was the first posttranslational modification identified (77) and the field has rapidly developed with the identification of enzymes that can either acetylate or deacetylate histones (21) and therefore lead to an opening of chromatin and subsequent transcription of relevant genes. On the contrary, nonacetylated histones are present in compact chromatin, also characterized by DNA hypermethylation at CpG. DNA and histone methyltransferase (DNMTs and HMTs), as well as histone acetyltransferase (HATs), are involved in plastic remodeling of chromatin as response to physiological and pathological stimuli (61). Together with histone deacetylases (HDACs) they regulate endothelial dysfunction and inflammation in T2D. One of the key families of deacetylases important in this setting are sirtuins (166), through the effects on vascular p66Shc gene transcription (SIRT1; 189). As a result, SIRT1 activation inhibits oxidative stress in the vessel wall and inhibits inflammation through prevention of NF- $\kappa \mathrm{B}$ activation and cleavage of PARP - the poly (ADP-ribose) polymerase (188). SIRT1 is downregulated in the AT of obese individuals leading to histone hyperacetylation, which enhances macrophage recruitment, TNF, IL-6, IL-1 $\beta$, TNF- $\alpha$, IL-13, IL-10, and IL-4 expression, and generalized AT inflammation (43).

Through their effects on NF- $\kappa \mathrm{B}$ activity, HATs and HDACs are important in controlling inflammation (166). HDAC3 regulates inflammatory genes in macrophages and HDAC2 contributes to resolution of inflammation (132). Role of SIRT1, HDAC4, enzyme involved in histone deacetylation is decreased in obesity and is correlated inversely to RANTES levels (2). T2D and T1D are both associated with increased $\mathrm{H} 3$ acetylation in the TNF- $\alpha$ and $\mathrm{COX} 2$ (cyclooxygenase 2) promoter regions, while $\mathrm{H} 3 \mathrm{~K} 4$ methylation renders dysfunctional monocytes through effects on NF- $\kappa \mathrm{B}$ dependent genes (132). Methylation of lysine residue 9 of histone 3 in lymphocytes affects their autoreactive potential in type 1 diabetes (100) and suppressing the H3K9 methylation is proinflammatory in the vasculature $(136,167)$. A growing body of evidence suggests that the mammalian methyltransferase Set7, involved in methylation of histones, may represent an important mechanism of vascular damage under hyperglycemic conditions $(32,114,153)$. In bovine and human ECs exposed to high glucose, Set7 induces monomethylation of lysine 4 of histone $3(\mathrm{H} 3 \mathrm{~K} 4 \mathrm{~m} 1)$ on the promoter of the RelA gene encoding for the transcription factor NF- $\kappa \mathrm{B}$ p 65 . This epigenetic modification by Set7 favors NF- $\kappa \mathrm{B}$ p 65 upregulation and resulting overexpression of adhesion molecules $(32,114,153)$. Interestingly, suppression of Set7-dependent epigenetic changes prevented hyperglycemiainduced inflammation (32). Despite these data, the role of Set7 in patients with diabetes mellitus remained unknown. Thus, we designed a study to investigate the link between Set7-induced chromatin changes and vascular phenotype in patients with T2D. Our findings demonstrated that a specific epigenetic signature induced by Set7 regulates $\mathrm{NF}-\kappa \mathrm{B}$ p65 expression and, hence, contributes to dysregulation of oxidant/inflammatory genes and endothelial dysfunction (118).

Targeting this chromatin-modifying enzyme may represent a promising approach to maintain vascular homeostasis (186) and reduce oxidative and inflammatory burden in this setting.

\section{Noncoding RNAs}

MicroRNAs (miRNAs) represent small noncoding RNAs that appear to play a key role regulating cardiovascular dysfunction in T2D (158). They posttranscriptionally regulate gene expression. Microarrays have demostrated a derangement of miRNA expression profile in patients with diabetes (185). Impairments of miRNAs involved in angiogenesis, inflammation, vascular repair, as well as endothelial homeostasis, have been reported $(75,104,185)$. One of the hallmark studies has identified key miRNAs altered in subjects with T2D, as potential biomarkers. Lower plasma levels of miR-20b, miR-21, miR-24, miR-15a, miR-126, miR-191, miR-197, miR-223, miR-320, and miR-486 were seen in T2D and a modest increase of miR-28-3p. Importantly, reduced miR-15a, miR-29b, miR-126, miR-223, and elevated miR28-3p levels antedated the manifestation of disease (185). Moreover, dysregulation of miRNAs within the AT, predominantly PVAT, has been linked to vascular disease, atherosclerosis, and aging (163). We recently investigated the miRNA landscape of the diabetic heart and its relationship with glycemic control (24). Our study was designed to address whether miRNAs may represent putative molecular drivers of hyperglycemic memory in the diabetic myocardium. miRNA landscape was assessed by miRNA polymerase chain reaction arrays in left ventricular specimens collected from streptozotocin-induced diabetic mice, with or without intensive glycemic control. We have shown that diabetes induces a profound alteration of miRNA expression in the heart and, most importantly, these detrimental signatures are not reverted by glycemic control (24). Such persistent alteration of several miRNAs orchestrating apoptosis, myocardial fibrosis, hypertrophy, autophagy, and redox signaling suggests the existence of hyperglycemic memory in the heart. Several miRNAs, which regulate inflammation, are decreased in T2D and aging, resulting in proinflammatory phenotype. MiR-21 has been widely associated with vascular aging and demonstrates concomitant effects on metabolic, inflammatory, and vascular mechanisms in the vessels and heart (Table 2; 29, 45, 180). While numerous other miRNAs have been implicated, miR$146 \mathrm{~b}$ (resulting in monocyte activation), miR-107, (resulting in TLR4 expression and increased macrophage responses), miR126 and miR-193b (resulting in enhanced chemotaxis) appear 


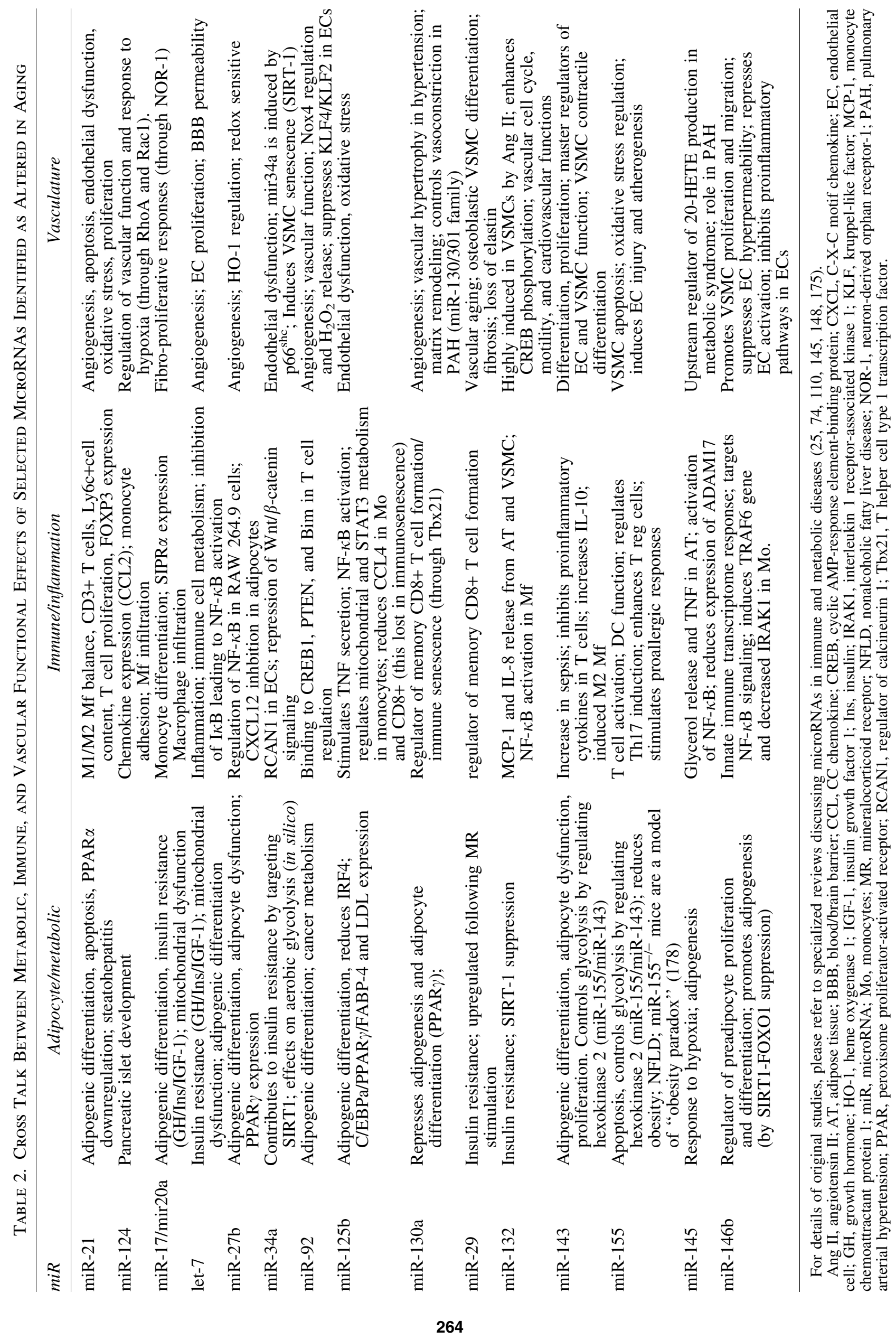


to be strongly linked to immunometabolism (132). Some proadipogenic and proinflammatory miRNAs are increased in T2D such as miR-103 and miR-143, resulting in increased adipocyte growth, altered adipokine profile, and insulin resistance (178), while miR-23b or novel miR-1298 is involved in VSMC phenotypic switching $(72,142)$. MiRNAs can also provide a molecular link between metabolic dysfunction and development of some of its complications such as hypertension $(18,95)$. Table 2 summarizes selected key miRNAs, which have been shown repetitively to regulate metabolic, immune, and vascular functions and diseases. Over the next few years, we will learn more about other types of noncoding RNAs in immune regulation, such as $l n c-D C$, which targets STAT3 or Lethe, which is induced by $\mathrm{TNF}$ and represses $\mathrm{NF}-\kappa \mathrm{B}$ target genes. These interesting new developments are reviewed elsewhere (80).

\section{Oxidative Stress, Vascular Inflammation, and Endothelial Insulin Resistance}

Impaired insulin signaling and high glucose are strongly interlinked with cardiovascular disease (CVD) in the setting of T2D $(12,56,59,154)$. This relationship is strongly mediated by reactive oxygen species (ROS), through their effects on vascular inflammation and dysfunction $(42,55,172)$. Insulin resistance precipitates the development of T2D and CVD (117). While links between hyperglycemia and oxidative stress are relatively clear, much less is known regarding the pathways through which free radicals regulate insulin resistance. Unquestionably, ROS contribute to altered insulin sensitivity in ECs. These effects may be, in part, direct and, in part, regulated by local low-grade inflammation promoted by oxidative stress. Vascular inflammation and atherosclerosis progression are directly linked to EC insulin signaling as demonstrated in $\mathrm{ApoE}^{-l-}$ mice $(27,135)$. Indeed, endothelialspecific overexpression of the inhibitory subunit of nuclear factor-kappa B $(\mathrm{I} \kappa-\mathrm{B} \alpha)$, which inhibits $\mathrm{NF}-\kappa \mathrm{B}$ activation, protects from insulin resistance in other organs (63). These findings cause a paradigm "shift" in the adipocentric theory (81). The novel concept that insulin resistance may primarily start in the endothelium is also strengthened by the fact that the endothelium lines the entire vascular system. Endothelial release of NO is essential for capillary recruitment and, hence, appropriate insulin delivery to hormone-sensitive organs (73). Accordingly, insulin-mediated glucose uptake is reduced in $\mathrm{eNOS}^{-1}$ compared with wild-type (WT) mice (10). Previous work has suggested that oxidative stress is a potent mediator of insulin resistance in ECs (27). Indeed, overexpression of free radical scavengers uncoupling protein 1 or manganese superoxide dismutase can restore endothelial NOS and prostacyclin $\left(\mathrm{PGI}_{2}\right)$ synthase activities, thus warranting insulin-dependent vasodilation and anti-inflammatory effects $(27,57)$. Moreover, vasodilatation induced by insulin may importantly regulate insulin-mediated glucose uptake (20, $85,133)$. Thus, restoration of endothelial function (measured as flow-mediated dilatation in human arteries) is clearly linked with an improvement of insulin sensitivity (106, 168). Key mechanistic markers of endothelial dysfunction and oxidative stress such as NF- $\kappa \mathrm{B}$ activity or protein kinase $\mathrm{C}$ (PKC) $\beta_{2}$ activity are elevated in the endothelium from patients with insulin resistance $(50,52,155)$. In relation to this, we have recently studied the role of mitochondrial adaptor $\mathrm{p} 66^{\mathrm{Shc}}$ in
ROS-driven insulin resistance in the ECs. p6 $6^{\text {Shc }}$ silencing in vivo restored endothelial function through modulation of the IRS-1/AKT/eNOS (120). Knockdown of $\mathrm{p} 66^{\text {Shc }}$ in endothelium from obese mice blunted free radical production and free fatty acid oxidation, key events favoring insulin resistance. Suppression of $\mathrm{p} 66^{\mathrm{Shc}}$-derived oxidative stress prevented dysregulation of NF- $\kappa \mathrm{B}$, advanced glycation end product (AGE) precursor methylglyoxal, and $\mathrm{PGI}_{2}$ synthase, biochemical effectors of maladaptive insulin signaling (120). In hypertension, angiotensin II infusion stimulates $\mathrm{T}$ cells to produce TNF, and etanercept (TNF- $\alpha$ antagonist) blunts vascular superoxide production (51). In macrophages, in turn, TNF-like weak inducer of apoptosis (TWEAK, Tnfsf12) and the receptor, fibroblast growth factor-inducible 14 (Fn14) promote ROS production and enhance nicotinamide adenine dinucleotide phosphate (NADPH) oxidase activity, which contributes to vascular damage and dysfunction in atherosclerosis (94).

A turn away from the sole "adipocentric" view of metabolic dysfunction origins is further supported by studies in mice with vascular smooth muscle-targeted deletion of p22phox subunit of the NADPH oxidase (183). p22phox is essential for activity of Nox1, Nox2, and possibly Nox4 NADPH oxidase, while Nox5 (not expressed in mice) is p22phox independent (47-50, 52, 143). These mice have significantly reduced vascular oxidative stress and are protected from endothelial dysfunction in a number of pathological conditions. Interestingly, high-fat feeding did not induce weight gain or leptin resistance in these mice, which was associated with strongly reduced $\mathrm{T}$ cell infiltration of perivascular fat. This is important as it indicates a causal immunometabolic link, suggesting that vascular dysfunction and inflammation may be primary, not secondary, in the development of obesity and insulin resistance (183). It also contributes to understanding of potential mechanisms of the inside-to-outside theory of the role of PVAT in vascular disease.

In T2D, increased glucose levels cause excessive free radical production from the mitochondria leading to the generation of AGEs, PKC activation, as well as increases in $\mathrm{NF}-\kappa \mathrm{B}$ (109). PKC $\beta_{2}$ isoform is associated with endothelial dysfunction through its effects on $\operatorname{ROS}(155) . P K C \beta_{2}$ elicits its deleterious effect through activation of mitochondrial and NADPH oxidases by regulating major components in ROS generation-namely $\mathrm{p} 66^{\text {Shc }}$ and $\mathrm{p} 47 \mathrm{phox}$ phosphorylation $(83,117)$. PKC inhibitor inhibits the NADPH oxidase activity $(46,55,131) . p 66^{\text {Shc-l- }}$ mice are protected against hyperglycemia-induced endothelial dysfunction and oxidative stress (17) and $\mathrm{p} 66^{\text {Shc }}$ expression is increased in lymphocytes and monocytes (PBMCs) from subjects with T2D. Moreover, p66 $6^{\text {Shc }}$ expression is correlated with plasma ROS marker (isoprostanes; 115). $\mathrm{PKC} \beta_{2}$, important in ROS generation, regulates of NF- $\kappa \mathrm{B}$ signaling in response to high glucose by reducing its $\mathrm{I} \kappa-\mathrm{B} \alpha$. This results in inflammatory activation of the ECs with increased VCAM-1 expression (83).

The role of NADPH oxidases in regulation of vascular inflammation in diabetes hypertension or atherosclerosis is well known, although recent studies have suggested additional important metabolic links. For example, Nox1-mediated increase in ROS induced by sphingosylphosphorylcholine leads to consequent enhancement of voltage-gated $\mathrm{Ca}^{2+}$ entry and thus vasoreactivity (146). 
Although the understanding of the regulation of oxidant and inflammatory genes remains challenging, it is clearly emerging that targeting specific molecular machineries may represent an interesting therapeutic possibility to reduce CVD in the setting of metabolic disease.

\section{Pathways Linking Aging and Immunometabolism}

An increased body of evidence shows a link between aging, CVD, and impaired metabolism. Not only aging impairs intracellular signaling triggering metabolic alterations but also metabolic conditions, such as obesity, diabetes, and insulin resistance, anticipate vascular and cardiac senescence. It is emerging that a dynamic interplay among p66 ${ }^{\text {Shc }}$, NADdependent deacetylase (Sirtuin 1; SIRT1), NF- $\kappa$ B, forkhead transcription factor (FOXO), AMPK, and activator protein-1 (AP-1) transcription factor JunD underlines pathologic cardiovascular phenotypes in this setting. Recent studies have demonstrated that the adaptor $\mathrm{p} 66^{\mathrm{Shc}}$ is an important molecular effector that may explain how aging relates to metabolic and CVD. Adaptor protein $\mathrm{p} 66^{\mathrm{Shc}}$ is an important source of intracellular ROS (22). On the contrary, $p 66^{\text {Shc-l- }}$ mouse models exposed to oxidative stimuli showed diminished ROS generation $(16,44)$. Several years ago, we observed that aging-induced impairment of endotheliumdependent relaxation to acetylcholine was not present in p66 $6^{\text {Shc-l- }}$ (38). Accordingly, NO availability was not reduced in aged $p 66^{\text {Shc-l- }}$ mice (38). Activation of $\mathrm{p} 66^{\text {Shc }}$ is indeed involved in adipogenesis, insulin resistance, and diabetes-related cardiovascular complications (13, 17). More recently, as already mentioned, we demonstrated an upregulation of $\mathrm{p} 66^{\mathrm{Shc}}$ in obese mice and the involvement in endothelial insulin resistance (120). Gene expression of p $66^{\text {Shc }}$ is increased in mononuclear cells obtained from patients with T2D and coronary artery disease $(39,115)$. Based on this background, it is possible to conclude that $\mathrm{p} 66^{\mathrm{Shc}}$ fosters ROS accumulation, derangement of mitochondrial function, insulin resistance, and diabetes. Mitochondrial dysfunction is characterized in diabetes (heart) by changes in mitochondrial structure and, mechanistically, complex I defect with oxidative stress results increased fatty acid oxidation (165). This effect is mediated by enhanced protein lysine acetylation (165).

SIRT-1, a member of the family of nicotinamide adenine dinucleotide-dependent proteins termed sirtuins, has recently emerged as an important regulator of cardiovascular aging and inflammation (127). SIRT-1 protects the heart against aging features (3). Aging-induced SIRT-1 downregulation leads to the translocation of NF- $\kappa \mathrm{B}$ p65 to the nucleus and hence increased expression of inflammatory genes (182). Epigenetic changes, such as increased DNA methylation and noncoding RNAs, modulate expression of sirtuins $(30,139$, 184). The maintenance of SIRT-1 homeostasis is crucial for the repression of pathways involved in arterial aging such as FOXO pathway (15). SIRT-1 also controls the release of protective factors such as recently identified Fgf21 in cardiac myocytes (128). Pharmacological inhibition of SIRT-1 protects against aging, impaired metabolic profiles, and cardiovascular complications (175). Among different compounds, resveratrol is an activator of SIRT-1. Resveratrol-increased SIRT-1 activity blunts the expression of oxidant and inflammatory genes by inducing epigenetic changes at the promoter level (34). Indeed, SIRT-1-induced histone deacetylation reduces the accessibility of transcription factors to chromatin, thereby blunting $\mathrm{p} 66^{\mathrm{Shc}}$ gene expression $(23,123)$. Downregulation of sirtuins in this setting favors transcription of FOXO-dependent genes leading to apoptosis, cell-cycle arrest, ROS generation, and impaired metabolism. NF- $\kappa \mathrm{B}$ is a transcription factor expressed in mammalian cells (124). Its activation triggers inflammatory pathways in the heart and vessels. It was recently shown that silencing of endothelial NF- $\kappa \mathrm{B}$ prolongs life span and improves endothelial insulin resistance in a mouse model of obesity. Selective endothelial overexpression of $\mathrm{NF}-\kappa \mathrm{B}$ inhibitory subunit was protective against insulin resistance in other tissues (63). Impaired insulin signaling is indeed an important hallmark linking metabolic disease with premature aging (134).

JunD, which is a member of the AP- 1 transcription factor family, is emerging as a key factor protecting from the development of vascular oxidative stress. AP-1 is a hetero- or homodimeric complex made of proteins belonging to the cFos, c-Jun, ATF (activating transcription factor), and CREB (cyclic AMP-response element-binding protein) families (68). The cellular environment (infections, stress, cytokines, and growth factors) regulates gene expression via AP-1 (68). JunD regulates cell growth and survival, through affecting antioxidant gene expression (41). This results in the fact that $J_{u n D^{-/-}}$mice are characterized by premature aging, shortened life span, and increased cancer development (86, 117, 159). JunD overexpression decreased oxidative stress and blunted redox signaling resulting in diminished cellular apoptosis $(41,117)$. JunD ${ }^{-1-}$ murine embryonic fibroblasts showed downregulation of antioxidant enzymes and increased NADPH oxidase expression (41). We demonstrated the relevance of JunD for cardiovascular homeostasis (122). We observed an aging-induced decrease of JunD expression leading to an imbalance between pro-oxidant and antioxidant enzymes with increased ROS production. Indeed, young mice lacking JunD showed early impairment of redox signaling, mitochondrial derangement, and endothelial dysfunction (86). Furthermore, the vascular senescence observed in young JunD $D^{-/-}$animals was similar to that observed in old WT mice. An adverse epigenetic remodeling occurring at the level of JunD promoter is responsible for such age-induced downregulation of JunD (86). This finding agrees with the notion that epigenetics affects the expression of genes involved in aging, dismetabolic profiles, and cardiovascular injury (159). In peripheral blood monocytes isolated from old compared to young healthy volunteers, JunD expression was reduced. In light of these findings, JunD can be considered as a promising target to prevent or delay age-induced CVD. Accordingly, disruption or upergulation of JunD expression promotes pressure-dependent cardiac apoptosis, hypertrophy, and angiogenesis (137) and blunt phenylephrine-mediated cardiomyocyte hypertrophy (66). In patients with severe heart failure, JunD protein expression is reduced (67). JunD ${ }^{-1-}$ mice show hyperinsulinemia, as a result of oxidative stress-induced pancreatic islet vascularization (86). Interestingly, the metabolic derangements found in $J u n D^{-/-}$mice were rescued by treatment with antioxidants (86). These data clearly indicate that JunD is an important effector in the interaction among aging, metabolism, and CVD. 


\section{Conclusion}

Vascular endothelial dysfunction, oxidative stress, and low-grade inflammation are common features of metabolic diseases and are closely interlinked. Glucose metabolism affects immune phenotype and regulates oxidative stress generating enzymes affecting the development of all features of vascular dysfunction. Recent studies suggest that vascular dysfunction, endothelial insulin resistance, and vascular inflammation may precede and cause the development of insulin resistance, obesity, and T2D rather than being their mere consequence. This change from the classical "adipocentric" theory of metabolic vascular disease may have significant diagnostic and therapeutic implications.

Distinct epigenetic changes in vascular cells, adipocytes, and immune cells are frequently observed in obesity and T2D, and these are associated with phenotypic and functional alterations of these cells. Targeting these chromatinmodifying enzymes may represent a promising approach to reduce oxidative and inflammatory burden in the setting of diabetic vascular dysfunction.

\section{Acknowledgments}

This article was supported by grants from Narodowe Centrum Nauki of Poland (2011/03/B/NZ4/02454, to T.J.G.); European Research Council project No. 726318, Marie Curie CIG (No. 631773), British Heart Foundation Centre for Research Excellence (RE/13/5/30177), and from Vetenskaprådet (No. 2016-02706), Swedish Heart-Lung Foundation (20140360), Konung Gustaf:Vs och Drottning Victorias Frimurarestiftelse (to F.C.).

\section{Author Disclosure Statement}

No competing financial interests exist.

\section{References}

1. 2017 IDF. Global Burden: Prevalence and Projections, 2015 and 2040. 2017. www.diabetesatlas.org/across-theglobe.html (accessed April 24, 2017).

2. Abu-Farha M, Tiss A, Abubaker J, Khadir A, Al-Ghimlas F, Al-Khairi I, Baturcam E, Cherian P, Elkum N, Hammad M, John J, Kavalakatt S, Warsame S, Behbehani K, Dermime S, and Dehbi M. Proteomics analysis of human obesity reveals the epigenetic factor HDAC4 as a potential target for obesity. PLoS One 8: e75342, 2013.

3. Alcendor RR, Gao S, Zhai P, Zablocki D, Holle E, Yu X, Tian B, Wagner T, Vatner SF, and Sadoshima J. Sirt1 regulates aging and resistance to oxidative stress in the heart. Circ Res 100: 1512-1521, 2007.

4. Alexander JS and Becker F. Dual signals underlying diabetic lymphatic barrier dysregulation. Cardiovasc Res 107: $3-4,2015$.

5. Almeida L, Lochner M, Berod L, and Sparwasser T. Metabolic pathways in $\mathrm{T}$ cell activation and lineage differentiation. Semin Immunol 28: 514-524, 2016.

6. Ammirati E, Cianflone D, Vecchio V, Banfi M, Vermi AC, De Metrio M, Grigore L, Pellegatta F, Pirillo A, Garlaschelli K, Manfredi AA, Catapano AL, Maseri A, Palini AG, and Norata GD. Effector memory $\mathrm{T}$ cells are associated with atherosclerosis in humans and animal models. $J$ Am Heart Assoc 1: 27-41, 2012.
7. Antonopoulos AS, Margaritis M, Coutinho P, Shirodaria C, Psarros C, Herdman L, Sanna F, De Silva R, Petrou M, Sayeed R, Krasopoulos G, Lee R, Digby J, Reilly S, Bakogiannis C, Tousoulis D, Kessler B, Casadei B, Channon $\mathrm{KM}$, and Antoniades C. Adiponectin as a link between type 2 diabetes and vascular NADPH oxidase activity in the human arterial wall: the regulatory role of perivascular adipose tissue. Diabetes 64: 2207-2219, 2015.

8. Antonopoulos AS, Margaritis M, Verheule S, Recalde A, Sanna F, Herdman L, Psarros C, Nasrallah H, Coutinho P, Akoumianakis I, Brewer AC, Sayeed R, Krasopoulos G, Petrou M, Tarun A, Tousoulis D, Shah AM, Casadei B, Channon KM, and Antoniades C. Mutual regulation of epicardial adipose tissue and myocardial redox state by PPAR-gamma/adiponectin signalling. Circ Res 118: 842-855, 2016.

9. Assar ME, Angulo J, and Rodriguez-Manas L. Diabetes and ageing-induced vascular inflammation. J Physiol 594: 2125-2146, 2016.

10. Avogaro A, de Kreutzenberg SV, Federici M, and Fadini GP. The endothelium abridges insulin resistance to premature aging. J Am Heart Assoc 2: e000262, 2013.

11. Barrat F, Lesourd B, Boulouis HJ, Thibault D, VincentNaulleau S, Gjata B, Louise A, Neway T, and Pilet C. Sex and parity modulate cytokine production during murine ageing. Clin Exp Immunol 109: 562-568, 1997.

12. Beckman JA, Paneni F, Cosentino F, and Creager MA. Diabetes and vascular disease: pathophysiology, clinical consequences, and medical therapy: part II. Eur Heart J 34: 2444-2452, 2013.

13. Berniakovich I, Trinei M, Stendardo M, Migliaccio E, Minucci S, Bernardi P, Pelicci PG, and Giorgio M. p66Shc-generated oxidative signal promotes fat accumulation. J Biol Chem 283: 34283-34293, 2008.

14. Bettelli E, Carrier Y, Gao W, Korn T, Strom TB, Oukka M, Weiner HL, and Kuchroo VK. Reciprocal developmental pathways for the generation of pathogenic effector TH17 and regulatory T cells. Nature 441: 235-238, 2006.

15. Brunet A, Sweeney LB, Sturgill JF, Chua KF, Greer PL, Lin Y, Tran H, Ross SE, Mostoslavsky R, Cohen HY, Hu LS, Cheng HL, Jedrychowski MP, Gygi SP, Sinclair DA, Alt FW, and Greenberg ME. Stress-dependent regulation of FOXO transcription factors by the SIRT1 deacetylase. Science 303: 2011-2015, 2004.

16. Camici GG, Cosentino F, Tanner FC, and Luscher TF. The role of p66Shc deletion in age-associated arterial dysfunction and disease states. J Appl Physiol (1985) 105: 1628-1631, 2008.

17. Camici GG, Schiavoni M, Francia P, Bachschmid M, Martin-Padura I, Hersberger M, Tanner FC, Pelicci $\mathrm{P}$, Volpe M, Anversa P, Luscher TF, and Cosentino F. Genetic deletion of p66(Shc) adaptor protein prevents hyperglycemia-induced endothelial dysfunction and oxidative stress. Proc Natl Acad Sci U S A 104: 5217-5222, 2007.

18. Carr G, Barrese V, Stott JB, Povstyan OV, Jepps TA, Figueiredo HB, Zheng D, Jamshidi Y, and Greenwood IA. MicroRNA-153 targeting of KCNQ4 contributes to vascular dysfunction in hypertension. Cardiovasc Res 112: 581-589, 2016.

19. Chatzigeorgiou A and Chavakis T. Immune cells and metabolism. Handb Exp Pharmacol 233: 221-249, 2016.

20. Clark MG, Wallis MG, Barrett EJ, Vincent MA, Richards SM, Clerk LH, and Rattigan S. Blood flow and muscle 
metabolism: a focus on insulin action. Am J Physiol Endocrinol Metab 284: E241-E258, 2003.

21. Cooper ME and El-Osta A. Epigenetics: mechanisms and implications for diabetic complications. Circ Res 107: 1403-1413, 2010.

22. Cosentino F, Francia P, Camici GG, Pelicci PG, Luscher TF, and Volpe M. Final common molecular pathways of aging and cardiovascular disease: role of the p66Shc protein. Arterioscler Thromb Vasc Biol 28: 622-628, 2008.

23. Costantino S, Paneni F, and Cosentino F. Targeting chromatin remodeling to prevent cardiovascular disease in diabetes. Curr Pharm Biotechnol 16: 531-543, 2015.

24. Costantino S, Paneni F, Luscher TF, and Cosentino F. MicroRNA profiling unveils hyperglycaemic memory in the diabetic heart. Eur Heart J 37: 572-576, 2016.

25. De Caterina R and Madonna R. Von Willebrand factor, ADAMTS13, and coronary microvascular obstruction: beautiful hypotheses, ugly facts. Cardiovasc Res 111: 169-171, 2016.

26. Dobrian AD, Hatcher MA, Brotman JJ, Galkina EV, Taghavie-Moghadam P, Pei H, Haynes BA, and Nadler JL. STAT4 contributes to adipose tissue inflammation and atherosclerosis. J Endocrinol 227: 13-24, 2015.

27. Du X, Edelstein D, Obici S, Higham N, Zou MH, and Brownlee $\mathrm{M}$. Insulin resistance reduces arterial prostacyclin synthase and eNOS activities by increasing endothelial fatty acid oxidation. J Clin Invest 116: 1071-1080, 2006.

28. Duca L, Blaise S, Romier B, Laffargue M, Gayral S, El Btaouri H, Kawecki C, Guillot A, Martiny L, Debelle L, and Maurice P. Matrix ageing and vascular impacts: focus on elastin fragmentation. Cardiovasc Res 110: 298-308, 2016.

29. Duygu B, Da Costa and Martins PA. miR-21: a star player in cardiac hypertrophy. Cardiovasc Res 105: 235-237, 2015.

30. Eades G, Yao Y, Yang M, Zhang Y, Chumsri S, and Zhou Q. miR-200a regulates SIRT1 expression and epithelial to mesenchymal transition (EMT)-like transformation in mammary epithelial cells. J Biol Chem 286: $25992-$ 26002, 2011.

31. Eerenberg ES, Teunissen PF, van den Born BJ, Meijers JC, Hollander MR, Jansen M, Tijssen R, Belien JA, van de Ven PM, Aly MF, Kamp O, Niessen HW, Kamphuisen PW, Levi M, and van Royen N. The role of ADAMTS13 in acute myocardial infarction: cause or consequence? Cardiovasc Res 111: 194-203, 2016.

32. El-Osta A, Brasacchio D, Yao D, Pocai A, Jones PL, Roeder RG, Cooper ME, and Brownlee M. Transient high glucose causes persistent epigenetic changes and altered gene expression during subsequent normoglycemia. $J$ Exp Med 205: 2409-2417, 2008.

33. Fasshauer M and Paschke R. Regulation of adipocytokines and insulin resistance. Diabetologia 46: 1594-1603, 2003.

34. Fernandez AF and Fraga MF. The effects of the dietary polyphenol resveratrol on human healthy aging and lifespan. Epigenetics 6: 870-874, 2011.

35. Feuerer M, Herrero L, Cipolletta D, Naaz A, Wong J, Nayer A, Lee J, Goldfine AB, Benoist C, Shoelson S, and Mathis D. Lean, but not obese, fat is enriched for a unique population of regulatory $\mathrm{T}$ cells that affect metabolic parameters. Nat Med 15: 930-939, 2009.
36. Finlay DK. Regulation of glucose metabolism in $\mathrm{T}$ cells: new insight into the role of Phosphoinositide 3-kinases. Front Immunol 3: 247, 2012.

37. Fischer HJ, Sie C, Schumann E, Witte AK, Dressel R, van den Brandt J, and Reichardt HM. The insulin receptor plays a critical role in $\mathrm{T}$ cell function and adaptive immunity. J Immunol 198: 1910-1920, 2017.

38. Francia P, delli Gatti C, Bachschmid M, Martin-Padura I, Savoia C, Migliaccio E, Pelicci PG, Schiavoni M, Luscher TF, Volpe M, and Cosentino F. Deletion of p66shc gene protects against age-related endothelial dysfunction. Circulation 110: 2889-2895, 2004.

39. Franzeck FC, Hof D, Spescha RD, Hasun M, Akhmedov A, Steffel J, Shi Y, Cosentino F, Tanner FC, von Eckardstein A, Maier W, Luscher TF, Wyss CA, and Camici GG. Expression of the aging gene p66Shc is increased in peripheral blood monocytes of patients with acute coronary syndrome but not with stable coronary artery disease. Atherosclerosis 220: 282-286, 2012.

40. Funck KL, Laugesen E, Ovrehus K, Jensen JM, Norgaard BL, Dey D, Hansen TK, and Poulsen PL. Increased highrisk coronary plaque burden is associated with arterial stiffness in patients with type 2 diabetes without clinical signs of coronary artery disease: a computed tomography angiography study. J Hypertens 35: 1235-1243, 2017.

41. Gerald D, Berra E, Frapart YM, Chan DA, Giaccia AJ, Mansuy D, Pouyssegur J, Yaniv M, and Mechta-Grigoriou F. JunD reduces tumor angiogenesis by protecting cells from oxidative stress. Cell 118: 781-794, 2004.

42. Giacco F and Brownlee M. Oxidative stress and diabetic complications. Circ Res 107: 1058-1070, 2010.

43. Gillum MP, Kotas ME, Erion DM, Kursawe R, Chatterjee P, Nead KT, Muise ES, Hsiao JJ, Frederick DW, Yonemitsu S, Banks AS, Qiang L, Bhanot S, Olefsky JM, Sears DD, Caprio S, and Shulman GI. SirT1 regulates adipose tissue inflammation. Diabetes 60: 3235-3245, 2011.

44. Giorgio M, Migliaccio E, Orsini F, Paolucci D, Moroni M, Contursi C, Pelliccia G, Luzi L, Minucci S, Marcaccio M, Pinton P, Rizzuto R, Bernardi P, Paolucci F, and Pelicci PG. Electron transfer between cytochrome c and p66Shc generates reactive oxygen species that trigger mitochondrial apoptosis. Cell 122: 221-233, 2005.

45. Gupta SK, Itagaki R, Zheng X, Batkai S, Thum S, Ahmad F, Van Aelst LN, Sharma A, Piccoli MT, Weinberger F, Fiedler J, Heuser M, Heymans S, Falk CS, Forster R, Schrepfer S, and Thum T. miR-21 promotes fibrosis in an acute cardiac allograft transplantation model. Cardiovasc Res 110: 215-226, 2016.

46. Guzik B, Sagan A, Ludew D, Mrowiecki W, Chwala M, Bujak-Gizycka B, Filip G, Grudzien G, Kapelak B, Zmudka K, Mrowiecki T, Sadowski J, Korbut R, and Guzik TJ. Mechanisms of oxidative stress in human aortic aneurysms-association with clinical risk factors for atherosclerosis and disease severity. Int J Cardiol 168: 2389-2396, 2013.

47. Guzik TJ, Chen W, Gongora MC, Guzik B, Lob HE, Mangalat D, Hoch N, Dikalov S, Rudzinski P, Kapelak B, Sadowski J, and Harrison DG. Calcium-dependent NOX5 nicotinamide adenine dinucleotide phosphate oxidase contributes to vascular oxidative stress in human coronary artery disease. J Am Coll Cardiol 52: 1803-1809, 2008.

48. Guzik TJ and Griendling KK. NADPH oxidases: molecular understanding finally reaching the clinical level? Antioxid Redox Signal 11: 2365-2370, 2009. 
49. Guzik TJ and Harrison DG. Vascular NADPH oxidases as drug targets for novel antioxidant strategies. Drug Discov Today 11: 524-533, 2006.

50. Guzik TJ and Harrison DG. Endothelial NF-kappaB as a mediator of kidney damage: the missing link between systemic vascular and renal disease? Circ Res 101: 227229, 2007.

51. Guzik TJ, Hoch NE, Brown KA, McCann LA, Rahman A, Dikalov S, Goronzy J, Weyand C, and Harrison DG. Role of the $\mathrm{T}$ cell in the genesis of angiotensin II induced hypertension and vascular dysfunction. J Exp Med 204: 2449-2460, 2007.

52. Guzik TJ, Korbut R, and Adamek-Guzik T. Nitric oxide and superoxide in inflammation and immune regulation. J Physiol Pharmacol 54: 469-487, 2003.

53. Guzik TJ, Mangalat D, and Korbut R. Adipocytokinesnovel link between inflammation and vascular function? J Physiol Pharmacol 57: 505-528, 2006.

54. Guzik TJ and Mikolajczyk T. In search of the T cell involved in hypertension and target organ damage. Hypertension 64: 224-226, 2014.

55. Guzik TJ, Mussa S, Gastaldi D, Sadowski J, Ratnatunga C, Pillai R, and Channon KM. Mechanisms of increased vascular superoxide production in human diabetes mellitus: role of $\mathrm{NAD}(\mathrm{P}) \mathrm{H}$ oxidase and endothelial nitric oxide synthase. Circulation 105: 1656-1662, 2002.

56. This reference has been deleted.

57. Guzik TJ, Olszanecki R, Sadowski J, Kapelak B, Rudzinski P, Jopek A, Kawczynska A, Ryszawa N, Loster J, Jawien J, Czesnikiewicz-Guzik M, Channon KM, and Korbut R. Superoxide dismutase activity and expression in human venous and arterial bypass graft vessels. J Physiol Pharmacol 56: 313-323, 2005.

58. Guzik TJ, Skiba D, Touyz RM, and Harrison DG. The role of infiltrating immune cells in dysfunctional adipose tissue. Cardiovasc Res 113: 1009-1023, 2017.

59. Guzik TJ, West NEJ, Black E, McDonald D, Ratnatunga C, Pillai R, and Channon KM. Vascular superoxide production by $\mathrm{NAD}(\mathrm{P}) \mathrm{H}$ oxidase: association with endothelial dysfunction and clinical risk factors. Circ Res 86: e85-e90, 2000.

60. Han JM, Patterson SJ, Speck M, Ehses JA, and Levings MK. Insulin inhibits IL-10-mediated regulatory $\mathrm{T}$ cell function: implications for obesity. J Immunol 192: 623629, 2014.

61. Handy DE, Castro R, and Loscalzo J. Epigenetic modifications: basic mechanisms and role in cardiovascular disease. Circulation 123: 2145-2156, 2011.

62. Hard GC. Some biochemical aspects of the immune macrophage. Br J Exp Pathol 51: 97-105, 1970.

63. Hasegawa Y, Saito T, Ogihara T, Ishigaki Y, Yamada T, Imai J, Uno K, Gao J, Kaneko K, Shimosawa T, Asano T, Fujita T, Oka Y, and Katagiri H. Blockade of the nuclear factor-kappaB pathway in the endothelium prevents insulin resistance and prolongs life spans. Circulation 125: 1122-1133, 2012.

64. Helderman JH. Role of insulin in the intermediary metabolism of the activated thymic-derived lymphocyte. J Clin Invest 67: 1636-1642, 1981.

65. Hermsdorff HH, Mansego ML, Campion J, Milagro FI, Zulet MA, and Martinez JA. TNF-alpha promoter methylation in peripheral white blood cells: relationship with circulating TNFalpha, truncal fat and n-6 PUFA intake in young women. Cytokine 64: 265-271, 2013.
66. Hilfiker-Kleiner D, Hilfiker A, Castellazzi M, Wollert KC, Trautwein C, Schunkert H, and Drexler H. JunD attenuates phenylephrine-mediated cardiomyocyte hypertrophy by negatively regulating AP-1 transcriptional activity. Cardiovasc Res 71: 108-117, 2006.

67. Hilfiker-Kleiner D, Hilfiker A, Kaminski K, Schaefer A, Park JK, Michel K, Quint A, Yaniv M, Weitzman JB, and Drexler H. Lack of JunD promotes pressure overloadinduced apoptosis, hypertrophic growth, and angiogenesis in the heart. Circulation 112: 1470-1477, 2005.

68. Hirai SI, Ryseck RP, Mechta F, Bravo R, and Yaniv M. Characterization of JunD: a new member of the Jun proto-oncogene family. EMBO J 8: 1433-1439, 1989.

69. Hiramatsu-Ito M, Shibata R, Ohashi K, Uemura Y, Kanemura N, Kambara T, Enomoto T, Yuasa D, Matsuo K, Ito M, Hayakawa S, Ogawa H, Otaka N, Kihara S, Murohara T, and Ouchi N. Omentin attenuates atherosclerotic lesion formation in apolipoprotein E-deficient mice. Cardiovasc Res 110: 107-117, 2016.

70. Hoefer IE, Steffens S, Ala-Korpela M, Back M, Badimon L, Bochaton-Piallat ML, Boulanger CM, Caligiuri G, Dimmeler S, Egido J, Evans PC, Guzik T, Kwak BR, Landmesser U, Mayr M, Monaco C, Pasterkamp G, Tunon $\mathrm{J}$, Weber C, Atherosclerosis ESCWG, and Vascular B. Novel methodologies for biomarker discovery in atherosclerosis. Eur Heart J 36: 2635-2642, 2015.

71. Hossain P, Kawar B, and El Nahas M. Obesity and diabetes in the developing world-a growing challenge. $N$ Engl J Med 356: 213-215, 2007.

72. Iaconetti C, De Rosa S, Polimeni A, Sorrentino S, Gareri C, Carino A, Sabatino J, Colangelo M, Curcio A, and Indolfi C. Down-regulation of miR-23b induces phenotypic switching of vascular smooth muscle cells in vitro and in vivo. Cardiovasc Res 107: 522-533, 2015.

73. Ignacak A, Kasztelnik M, Sliwa T, Korbut RA, Rajda K, and Guzik TJ. Prolactin-not only lactotrophin. A "new" view of the "old" hormone. J Physiol Pharmacol 63: 435-443, 2012.

74. Interleukin-6 Receptor Mendelian Randomisation Analysis (IL6R MR) Consortium, Swerdlow DI, Holmes MV, Kuchenbaecker KB, Engmann JE, Shah T, Sofat R, Guo Y, Chung C, Peasey A, Pfister R, Mooijaart SP, Ireland HA, Leusink M, Langenberg C, Li KW, Palmen J, Howard P, Cooper JA, Drenos F, Hardy J, Nalls MA, Li YR, Lowe G, Stewart M, Bielinski SJ, Peto J, Timpson NJ, Gallacher J, Dunlop M, Houlston R, Tomlinson I, Tzoulaki I, Luan J, Boer JM, Forouhi NG, Onland-Moret NC, van der Schouw YT, Schnabel RB, Hubacek JA, Kubinova R, Baceviciene M, Tamosiunas A, Pajak A, ToporMadry R, Malyutina S, Baldassarre D, Sennblad B, Tremoli E, de Faire U, Ferrucci L, Bandenelli S, Tanaka T, Meschia JF, Singleton A, Navis G, Mateo Leach I, Bakker SJ, Gansevoort RT, Ford I, Epstein SE, Burnett MS, Devaney JM, Jukema JW, Westendorp RG, Jan de Borst G, van der Graaf Y, de Jong PA, Mailand-van der Zee AH, Klungel OH, de Boer A, Doevendans PA, Stephens JW, Eaton CB, Robinson JG, Manson JE, Fowkes FG, Frayling TM, Price JF, Whincup PH, Morris RW, Lawlor DA, Smith GD, Ben-Shlomo Y, Redline S, Lange LA, Kumari M, Wareham NJ, Verschuren WM, Benjamin EJ, Whittaker JC, Hamsten A, Dudbridge F, Delaney JA, Wong A, Kuh D, Hardy R, Castillo BA, Connolly JJ, van der Harst P, Brunner EJ, Marmot MG, Wassel CL, Humphries SE, Talmud PJ, Kivimaki M, Asselbergs FW, Voevoda M, 
Bobak M, Pikhart H, Wilson JG, Hakonarson H, Reiner AP, Keating BJ, Sattar N, Hingorani AD, and Casas JP. The interleukin-6 receptor as a target for prevention of coronary heart disease: a mendelian randomisation analysis. Lancet 379: 1214-1224, 2012.

75. Jansen F, Yang X, Hoelscher M, Cattelan A, Schmitz T, Proebsting S, Wenzel D, Vosen S, Franklin BS, Fleischmann BK, Nickenig G, and Werner N. Endothelial microparticle-mediated transfer of MicroRNA-126 promotes vascular endothelial cell repair via SPRED1 and is abrogated in glucose-damaged endothelial microparticles. Circulation 128: 2026-2038, 2013.

76. Kang KY, Kim YK, Yi H, Kim J, Jung HR, Kim IJ, Cho JH, Park SH, Kim HY, and Ju JH. Metformin downregulates Th17 cells differentiation and attenuates murine autoimmune arthritis. Int Immunopharmacol 16: 85-92, 2013.

77. Keating ST and El-Osta A. Chromatin modifications associated with diabetes. J Cardiovasc Transl Res 5: 399412, 2012.

78. Keating ST, Plutzky J, and El-Osta A. Epigenetic changes in diabetes and cardiovascular risk. Circ Res 118: 17061722, 2016.

79. Kim GH, Ryan JJ, and Archer SL. The role of redox signaling in epigenetics and cardiovascular disease. Antioxid Redox Signal 18: 1920-1936, 2013.

80. Kim J, Kim KM, Noh JH, Yoon JH, Abdelmohsen K, and Gorospe M. Long noncoding RNAs in diseases of aging. Biochim Biophys Acta 1859: 209-221, 2016.

81. Kim JK. Endothelial nuclear factor kappaB in obesity and aging: is endothelial nuclear factor kappaB a master regulator of inflammation and insulin resistance? Circulation 125: 1081-1083, 2012.

82. Kossmann S, Schwenk M, Hausding M, Karbach SH, Schmidgen MI, Brandt M, Knorr M, Hu H, Kroller-Schon S, Schonfelder T, Grabbe S, Oelze M, Daiber A, Munzel $\mathrm{T}$, Becker C, and Wenzel P. Angiotensin II-induced vascular dysfunction depends on interferon-gamma-driven immune cell recruitment and mutual activation of monocytes and NK-cells. Arterioscler Thromb Vasc Biol 33: 1313-1319, 2013.

83. Kouroedov A, Eto M, Joch H, Volpe M, Luscher TF, and Cosentino F. Selective inhibition of protein kinase Cbeta2 prevents acute effects of high glucose on vascular cell adhesion molecule-1 expression in human endothelial cells. Circulation 110: 91-96, 2004.

84. La Cava A and Matarese G. The weight of leptin in immunity. Nat Rev Immunol 4: 371-379, 2004.

85. Laakso M, Edelman SV, Brechtel G, and Baron AD. Decreased effect of insulin to stimulate skeletal muscle blood flow in obese man. A novel mechanism for insulin resistance. J Clin Invest 85: 1844-1852, 1990.

86. Laurent G, Solari F, Mateescu B, Karaca M, Castel J, Bourachot B, Magnan C, Billaud M, and MechtaGrigoriou F. Oxidative stress contributes to aging by enhancing pancreatic angiogenesis and insulin signaling. Cell Metab 7: 113-124, 2008.

87. Lesourd BM. Nutrition and immunity in the elderly: modification of immune responses with nutritional treatments. Am J Clin Nutr 66: 478S-484S, 1997.

88. Liu L, Li Y, and Tollefsbol TO. Gene-environment interactions and epigenetic basis of human diseases. Curr Issues Mol Biol 10: 25-36, 2008.

89. Liu Y, Wang Y, Shi H, Jia L, Cheng J, Cui W, Li H, Li $\mathrm{P}$, and Du J. CARD9 mediates necrotic smooth muscle cell-induced inflammation in macrophages contributing to neointima formation of vein grafts. Cardiovasc Res 108: 148-158, 2015.

90. Lumeng CN, Bodzin JL, and Saltiel AR. Obesity induces a phenotypic switch in adipose tissue macrophage polarization. J Clin Invest 117: 175-184, 2007.

91. Lumeng CN, Deyoung SM, and Saltiel AR. Macrophages block insulin action in adipocytes by altering expression of signaling and glucose transport proteins. Am J Physiol Endocrinol Metab 292: E166-E174, 2007.

92. Ma Y, Chiao YA, Clark R, Flynn ER, Yabluchanskiy A, Ghasemi O, Zouein F, Lindsey ML, and Jin YF. Deriving a cardiac ageing signature to reveal MMP-9-dependent inflammatory signalling in senescence. Cardiovasc Res 106: 421-431, 2015.

93. MacIver NJ, Michalek RD, and Rathmell JC. Metabolic regulation of T lymphocytes. Annu Rev Immunol 31: 259283, 2013.

94. Madrigal-Matute J, Fernandez-Laso V, Sastre C, LlamasGranda P, Egido J, Martin-Ventura JL, Zalba G, and Blanco-Colio LM. TWEAK/Fn14 interaction promotes oxidative stress through NADPH oxidase activation in macrophages. Cardiovasc Res 108: 139-147, 2015.

95. Maffei A, Di Mauro V, Catalucci D, and Lembo G. MiR153/Kv7.4: a novel molecular axis in the regulation of hypertension. Cardiovasc Res 112: 30-531, 2016.

96. Margaritis M, Antonopoulos AS, Digby J, Lee R, Reilly S, Coutinho P, Shirodaria C, Sayeed R, Petrou M, De Silva $\mathrm{R}$, Jalilzadeh S, Demosthenous M, Bakogiannis C, Tousoulis D, Stefanadis C, Choudhury RP, Casadei B, Channon KM, and Antoniades $\mathrm{C}$. Interactions between vascular wall and perivascular adipose tissue reveal novel roles for adiponectin in the regulation of endothelial nitric oxide synthase function in human vessels. Circulation 127: 2209-2221, 2013.

97. Marvar PJ, Thabet SR, Guzik TJ, Lob HE, McCann LA, Weyand C, Gordon FJ, and Harrison DG. Central and peripheral mechanisms of T-lymphocyte activation and vascular inflammation produced by angiotensin II-induced hypertension. Circ Res 107: 263-270, 2010.

98. Matusik P, Guzik B, Weber C, and Guzik TJ. Do we know enough about the immune pathogenesis of acute coronary syndromes to improve clinical practice? Thromb Haemost 108: 443-456, 2012.

99. McMaster WG, Kirabo A, Madhur MS, and Harrison DG. Inflammation, immunity, and hypertensive end-organ damage. Circ Res 116: 1022-1033, 2015.

100. Miao F, Smith DD, Zhang L, Min A, Feng W, and Natarajan R. Lymphocytes from patients with type 1 diabetes display a distinct profile of chromatin histone $\mathrm{H} 3$ lysine 9 dimethylation: an epigenetic study in diabetes. Diabetes 57: 3189-3198, 2008.

101. Michalek RD, Gerriets VA, Jacobs SR, Macintyre AN, MacIver NJ, Mason EF, Sullivan SA, Nichols AG, and Rathmell JC. Cutting edge: distinct glycolytic and lipid oxidative metabolic programs are essential for effector and regulatory CD4+ T cell subsets. J Immunol 186: 3299-3303, 2011.

102. Mikolajczyk TP, Nosalski R, Szczepaniak P, Budzyn K, Osmenda G, Skiba D, Sagan A, Wu J, Vinh A, Marvar PJ, Guzik B, Podolec J, Drummond G, Lob HE, Harrison DG, and Guzik TJ. Role of chemokine RANTES in the regulation of perivascular inflammation, T-cell accumulation, and vascular dysfunction in hypertension. FASEB $J 30$ : 1987-1999, 2016. 
103. Mikolajczyk TP, Osmenda G, Batko B, Wilk G, Krezelok M, Skiba D, Sliwa T, Pryjma JR, and Guzik TJ. Heterogeneity of peripheral blood monocytes, endothelial dysfunction and subclinical atherosclerosis in patients with systemic lupus erythematosus. Lupus 25: 18-27, 2016.

104. Mocharla P, Briand S, Giannotti G, Dorries C, Jakob P, Paneni F, Luscher T, and Landmesser U. AngiomiR-126 expression and secretion from circulating CD34(+) and CD14(+) PBMCs: role for proangiogenic effects and alterations in type 2 diabetics. Blood 121: 226-236, 2013.

105. Molofsky AB, Nussbaum JC, Liang HE, Van Dyken SJ, Cheng LE, Mohapatra A, Chawla A, and Locksley RM. Innate lymphoid type 2 cells sustain visceral adipose tissue eosinophils and alternatively activated macrophages. $J$ Exp Med 210: 535-549, 2013.

106. Naka KK, Papathanassiou K, Bechlioulis A, Pappas K, Kazakos N, Kanioglou C, Papafaklis MI, Kostoula A, Vezyraki P, Makriyiannis D, Tsatsoulis A, and Michalis LK. Rosiglitazone improves endothelial function in patients with type 2 diabetes treated with insulin. Diab Vasc Dis Res 8: 195-201, 2011.

107. Newton R, Priyadharshini B, and Turka LA. Immunometabolism of regulatory T cells. Nat Immunol 17: 618-625, 2016.

108. Nguyen Dinh Cat A, Montezano AC, Burger D, and Touyz RM. Angiotensin II, NADPH oxidase, and redox signaling in the vasculature. Antioxid Redox Signal 19: 1110-1120, 2013.

109. Nishikawa T, Edelstein D, Du XL, Yamagishi S, Matsumura T, Kaneda Y, Yorek MA, Beebe D, Oates PJ, Hammes HP, Giardino I, and Brownlee M. Normalizing mitochondrial superoxide production blocks three pathways of hyperglycaemic damage. Nature 404: 787-790, 2000.

110. Nishimura S, Manabe I, Nagasaki M, Eto K, Yamashita H, Ohsugi M, Otsu M, Hara K, Ueki K, Sugiura S, Yoshimura K, Kadowaki T, and Nagai R. CD8+ effector T cells contribute to macrophage recruitment and adipose tissue inflammation in obesity. Nat Med 15: 914-920, 2009.

111. Noh M. Interleukin-17A increases leptin production in human bone marrow mesenchymal stem cells. Biochem Pharmacol 83: 661-670, 2012.

112. Norata GD, Caligiuri G, Chavakis T, Matarese G, Netea MG, Nicoletti A, O'Neill LA, and Marelli-Berg FM. The cellular and molecular basis of translational immunometabolism. Immunity 43: 421-434, 2015.

113. Nosalski R and Guzik TJ. Perivascular adipose tissue inflammation in vascular disease. Br J Pharmacol 174: 34963513, 2017.

114. Okabe J, Orlowski C, Balcerczyk A, Tikellis C, Thomas $\mathrm{MC}$, Cooper ME, and El-and Osta A. Distinguishing hyperglycemic changes by Set7 in vascular endothelial cells. Circ Res 110: 1067-1076, 2012.

115. Pagnin E, Fadini G, de Toni R, Tiengo A, Calo L, and Avogaro A. Diabetes induces p66shc gene expression in human peripheral blood mononuclear cells: relationship to oxidative stress. J Clin Endocrinol Metab 90: 1130-1136, 2005.

116. Palsson-McDermott EM, Curtis AM, Goel G, Lauterbach MA, Sheedy FJ, Gleeson LE, van den Bosch MW, Quinn SR, Domingo-Fernandez R, Johnston DG, Jiang JK, Israelsen WJ, Keane J, Thomas C, Clish C, Vander Heiden M, Xavier RJ, and O'Neill LA. Pyruvate kinase M2 regulates HIF-1alpha activity and IL-1beta induction and is a critical determinant of the warburg effect in LPS-activated macrophages. Cell Metab 21: 65-80, 2015.
117. Paneni F, Beckman JA, Creager MA, and Cosentino F. Diabetes and vascular disease: pathophysiology, clinical consequences, and medical therapy: part I. Eur Heart $J$ 34: 2436-2443, 2013.

118. Paneni F, Costantino S, Battista R, Castello L, Capretti G, Chiandotto S, Scavone G, Villano A, Pitocco D, Lanza G, Volpe M, Luscher TF, and Cosentino F. Adverse epigenetic signatures by histone methyltransferase Set7 contribute to vascular dysfunction in patients with type 2 diabetes mellitus. Circ Cardiovasc Genet 8: 150-158, 2015.

119. Paneni F, Costantino S, and Cosentino F. Insulin resistance, diabetes, and cardiovascular risk. Curr Atheroscler Rep 16: 419, 2014.

120. Paneni F, Costantino S, and Cosentino F. p66(Shc)induced redox changes drive endothelial insulin resistance. Atherosclerosis 236: 426-429, 2014.

121. Paneni F, Mocharla P, Akhmedov A, Costantino S, Osto E, Volpe M, Luscher TF, and Cosentino F. Gene silencing of the mitochondrial adaptor p66(Shc) suppresses vascular hyperglycemic memory in diabetes. Circ Res 111: 278289, 2012.

122. Paneni F, Osto E, Costantino S, Mateescu B, Briand S, Coppolino G, Perna E, Mocharla P, Akhmedov A, Kubant R, Rohrer L, Malinski T, Camici GG, Matter CM, Mechta-Grigoriou F, Volpe M, Luscher TF, and Cosentino F. Deletion of the activated protein-1 transcription factor JunD induces oxidative stress and accelerates age-related endothelial dysfunction. Circulation 127: 1229.e11240.e21, 2013.

123. Paneni F, Volpe M, Luscher TF, and Cosentino F. SIRT1, p66(Shc), and Set7/9 in vascular hyperglycemic memory: bringing all the strands together. Diabetes 62: 1800-1807, 2013.

124. Patterson C, Ruef J, Madamanchi NR, Barry-Lane P, Hu $\mathrm{Z}$, Horaist $\mathrm{C}$, Ballinger $\mathrm{CA}$, Brasier $\mathrm{AR}$, Bode $\mathrm{C}$, and Runge MS. Stimulation of a vascular smooth muscle cell NAD(P)H oxidase by thrombin. evidence that p47(phox) may participate in forming this oxidase in vitro and in vivo. J Biol Chem 274: 19814-19822, 1999.

125. Pearce EL and Pearce EJ. Metabolic pathways in immune cell activation and quiescence. Immunity 38: 633643, 2013.

126. Pei H, Gu J, Thimmalapura PR, Mison A, and Nadler JL. Activation of the 12-lipoxygenase and signal transducer and activator of transcription pathway during neointima formation in a model of the metabolic syndrome. Am J Physiol Endocrinol Metab 290: E92-E102, 2006.

127. Pillarisetti S. A review of Sirt1 and Sirt1 modulators in cardiovascular and metabolic diseases. Recent Pat Cardiovasc Drug Discov 3: 156-164, 2008.

128. Planavila A, Redondo-Angulo I, Ribas F, Garrabou G, Casademont J, Giralt M, and Villarroya F. Fibroblast growth factor 21 protects the heart from oxidative stress. Cardiovasc Res 106: 19-31, 2015.

129. Podolec J, Kopec G, Niewiara L, Komar M, Guzik B, Bartus K, Tomkiewicz-Pajak L, Guzik TJ, Plazak W, and Zmudka K. Chemokine RANTES is increased at early stages of coronary artery disease. J Physiol Pharmacol 67: 321-328, 2016.

130. Polyzos KA, Ovchinnikova O, Berg M, Baumgartner R, Agardh H, Pirault J, Gistera A, Assinger A, LagunaFernandez A, Back M, Hansson GK, and Ketelhuth DF. Inhibition of indoleamine 2,3-dioxygenase promotes 
vascular inflammation and increases atherosclerosis in Apoe $^{-1-}$ mice. Cardiovasc Res 106: 295-302, 2015.

131. Quagliaro L, Piconi L, Assaloni R, Martinelli L, Motz E, and Ceriello A. Intermittent high glucose enhances apoptosis related to oxidative stress in human umbilical vein endothelial cells: the role of protein kinase $\mathrm{C}$ and $\mathrm{NAD}(\mathrm{P}) \mathrm{H}-$ oxidase activation. Diabetes 52: 2795-2804, 2003.

132. Raghuraman S, Donkin I, Versteyhe S, Barres R, and Simar D. The emerging role of epigenetics in inflammation and immunometabolism. Trends Endocrinol Metab 27: 782-795, 2016.

133. Rask-Madsen C and Kahn CR. Tissue-specific insulin signaling, metabolic syndrome, and cardiovascular disease. Arterioscler Thromb Vasc Biol 32: 2052-2059, 2012.

134. Rask-Madsen C and King GL. Endothelium-dependent delivery of insulin to muscle interstitium. Cell Metab 13: 236-238, 2011.

135. Rask-Madsen C, Li Q, Freund B, Feather D, Abramov R, Wu IH, Chen K, Yamamoto-Hiraoka J, Goldenbogen J, Sotiropoulos KB, Clermont A, Geraldes P, Dall'Osso C, Wagers AJ, Huang PL, Rekhter M, Scalia R, Kahn CR, and King GL. Loss of insulin signaling in vascular endothelial cells accelerates atherosclerosis in apolipoprotein E null mice. Cell Metab 11: 379-389, 2010.

136. Reddy MA, Villeneuve LM, Wang M, Lanting L, and Natarajan R. Role of the lysine-specific demethylase 1 in the proinflammatory phenotype of vascular smooth muscle cells of diabetic mice. Circ Res 103: 615-623, 2008.

137. Ricci R, Eriksson U, Oudit GY, Eferl R, Akhmedov A, Sumara I, Sumara G, Kassiri Z, David JP, Bakiri L, Sasse B, Idarraga MH, Rath M, Kurz D, Theussl HC, Perriard JC, Backx P, Penninger JM, and Wagner EF. Distinct functions of junD in cardiac hypertrophy and heart failure. Genes Dev 19: 208-213, 2005.

138. Sagan A, Mrowiecki W, Mikolajczyk TP, Urbanski K, Siedlinski M, Nosalski R, Korbut R, and Guzik TJ. Local inflammation is associated with aortic thrombus formation in abdominal aortic aneurysms. Relationship to clinical risk factors. Thromb Haemost 108: 812-823, 2012.

139. Sahin K, Yilmaz S, and Gozukirmizi N. Changes in human sirtuin 6 gene promoter methylation during aging. Biomed Rep 2: 574-578, 2014.

140. Scallan JP, Hill MA, and Davis MJ. Lymphatic vascular integrity is disrupted in type 2 diabetes due to impaired nitric oxide signalling. Cardiovasc Res 107: 89-97, 2015.

141. Scheiermann C, Frenette PS, and Hidalgo A. Regulation of leucocyte homeostasis in the circulation. Cardiovasc Res 107: 340-351, 2015.

142. Schmidt K and de Wit C. Keep calm and carry on: miR1298 prevents up-regulation of $\mathrm{Cx} 43$ and secures a quiescent vascular smooth muscle cell. Cardiovasc Res 107: 407-409, 2015.

143. Schramm A, Matusik P, Osmenda G, and Guzik TJ. Targeting NADPH oxidases in vascular pharmacology. Vascul Pharmacol 56: 216-231, 2012.

144. Scuteri A, Cunha PG, Rosei EA, Badariere J, Bekaert S, Cockcroft JR, Cotter J, Cucca F, De Buyzere ML, De Meyer T, Ferrucci L, Franco O, Gale N, Gillebert TC, Hofman A, Langlois M, Laucevicius A, Laurent S, Mattace Raso FU, Morrell CH, Muiesan ML, Munnery MM, Navickas R, Oliveira P, Orru M, Pilia MG, Rietzschel ER, Ryliskyte L, Salvetti M, Schlessinger D, Sousa N, Stefanadis C, Strait J, Van daele C, Villa I, Vlachopoulos C, Witteman J, Xaplanteris P, Nilsson P, Lakatta EG, and
Consortium M. Arterial stiffness and influences of the metabolic syndrome: a cross-countries study. Atherosclerosis 233: 654-660, 2014.

145. Sell H, Habich C, and Eckel J. Adaptive immunity in obesity and insulin resistance. Nat Rev Endocrinol 8: 709716, 2012.

146. Shaifta Y, Snetkov VA, Prieto-Lloret J, Knock GA, Smirnov SV, Aaronson PI, and Ward JP. Sphingosylphosphorylcholine potentiates vasoreactivity and voltagegated $\mathrm{Ca} 2+$ entry via NOX1 and reactive oxygen species. Cardiovasc Res 106: 121-130, 2015.

147. Shi H, Kokoeva MV, Inouye K, Tzameli I, Yin H, and Flier JS. TLR4 links innate immunity and fatty acidinduced insulin resistance. J Clin Invest 116: 3015-3025, 2006.

148. Shirakawa K, Yan X, Shinmura K, Endo J, Kataoka M, Katsumata Y, Yamamoto T, Anzai A, Isobe S, Yoshida N, Itoh H, Manabe I, Sekai M, Hamazaki Y, Fukuda K, Minato N, and Sano M. Obesity accelerates T cell senescence in murine visceral adipose tissue. $J$ Clin Invest 126: 4626-4639, 2016.

149. Simar D, Versteyhe S, Donkin I, Liu J, Hesson L, Nylander V, Fossum A, and Barres R. DNA methylation is altered in B and NK lymphocytes in obese and type 2 diabetic human. Metabolism 63: 1188-1197, 2014.

150. Skiba DS, Nosalski R, Mikolajczyk TP, Siedlinski M, Rios FJ, Montezano AC, Jawien J, Olszanecki R, Korbut R, Czesnikiewicz-Guzik M, Touyz RM, and Guzik TJ. Antiatherosclerotic effect of Ang- (1-7) non-peptide mimetic (AVE 0991) is mediated by inhibition of perivascular and plaque inflammation in early atherosclerosis. $\mathrm{Br}$ J Pharmacol 174: 4055-4069, 2017.

151. Son HJ, Lee J, Lee SY, Kim EK, Park MJ, Kim KW, Park $\mathrm{SH}$, and Cho ML. Metformin attenuates experimental autoimmune arthritis through reciprocal regulation of Th17/Treg balance and osteoclastogenesis. Mediators Inflamm 2014: 973986, 2014.

152. Spigoni V, Aldigeri R, Picconi A, Derlindati E, Franzini L, Haddoub S, Prampolini G, Vigna GB, Zavaroni I, Bonadonna RC, and Dei Cas A. Telomere length is independently associated with subclinical atherosclerosis in subjects with type 2 diabetes: a cross-sectional study. Acta Diabetol 53: 661-667, 2016.

153. Sun G, Reddy MA, Yuan H, Lanting L, Kato M, and Natarajan R. Epigenetic histone methylation modulates fibrotic gene expression. J Am Soc Nephrol 21: 20692080, 2010.

154. Szopa M, Osmenda G, Wilk G, Matejko B, Skupien J, Zapala B, Mlynarski W, Guzik T, and Malecki MT. Intima-media thickness and endothelial dysfunction in GCK and HNF1A-MODY patients. Eur J Endocrinol 172: 277-283, 2015.

155. Tabit CE, Shenouda SM, Holbrook M, Fetterman JL, Kiani S, Frame AA, Kluge MA, Held A, Dohadwala MM, Gokce N, Farb MG, Rosenzweig J, Ruderman N, Vita JA, and Hamburg NM. Protein kinase C-beta contributes to impaired endothelial insulin signaling in humans with diabetes mellitus. Circulation 127: 86-95, 2013.

156. Tajbakhsh S, Aliakbari K, Hussey DJ, Lower KM, Donato AJ, and Sokoya EM. Differential telomere shortening in blood versus arteries in an animal model of type 2 diabetes. J Diabetes Res 2015: 153829, 2015.

157. Tamas P, Hawley SA, Clarke RG, Mustard KJ, Green K, Hardie DG, and Cantrell DA. Regulation of the energy 
sensor AMP-activated protein kinase by antigen receptor and Ca2+ in T lymphocytes. J Exp Med 203: 1665-1670, 2006.

158. Thum $\mathrm{T}$ and Condorelli G. Long noncoding RNAs and microRNAs in cardiovascular pathophysiology. Circ Res 116: 751-762, 2015.

159. Toullec A, Gerald D, Despouy G, Bourachot B, Cardon M, Lefort S, Richardson M, Rigaill G, Parrini MC, Lucchesi C, Bellanger D, Stern MH, Dubois T, Sastre-Garau $\mathrm{X}$, Delattre O, Vincent-Salomon A, and Mechta-Grigoriou F. Oxidative stress promotes myofibroblast differentiation and tumour spreading. EMBO Mol Med 2: 211-230, 2010.

160. Trifari S, Kaplan CD, Tran EH, Crellin NK, and Spits H. Identification of a human helper $\mathrm{T}$ cell population that has abundant production of interleukin 22 and is distinct from $\mathrm{T}(\mathrm{H})-17, \mathrm{~T}(\mathrm{H}) 1$ and $\mathrm{T}(\mathrm{H}) 2$ cells. Nat Immunol 10: 864-871, 2009.

161. Urbanski K, Ludew D, Filip G, Filip M, Sagan A, Szczepaniak P, Grudzien G, Sadowski J, JasiewiczHonkisz B, Sliwa T, Kapelak B, McGinnigle E, Mikolajczyk T, and Guzik T. CD14+CD16++ "nonclassical" monocytes are associated with endothelial dysfunction in patients with coronary artery disease. Thromb Hemost 117 : 971-980, 2017.

162. Uziel O, Singer JA, Danicek V, Sahar G, Berkov E, Luchansky M, Fraser A, Ram R, and Lahav M. Telomere dynamics in arteries and mononuclear cells of diabetic patients: effect of diabetes and of glycemic control. Exp Gerontol 42: 971-978, 2007.

163. Vacca M, Di Eusanio M, Cariello M, Graziano G, D'Amore S, Petridis FD, D'Orazio A, Salvatore L, Tamburro A, Folesani G, Rutigliano D, Pellegrini F, Sabba C, Palasciano G, Di Bartolomeo R, and Moschetta A. Integrative miRNA and whole-genome analyses of epicardial adipose tissue in patients with coronary atherosclerosis. Cardiovasc Res 109: 228-239, 2016.

164. Vandanmagsar B, Youm YH, Ravussin A, Galgani JE, Stadler K, Mynatt RL, Ravussin E, Stephens JM, and Dixit VD. The NLRP3 inflammasome instigates obesityinduced inflammation and insulin resistance. Nat Med 17: 179-188, 2011.

165. Vazquez EJ, Berthiaume JM, Kamath V, Achike O, Buchanan E, Montano MM, Chandler MP, Miyagi M, and Rosca MG. Mitochondrial complex I defect and increased fatty acid oxidation enhance protein lysine acetylation in the diabetic heart. Cardiovasc Res 107: 453-465, 2015.

166. Villeneuve LM and Natarajan R. The role of epigenetics in the pathology of diabetic complications. Am J Physiol Renal Physiol 299: F14-F25, 2010.

167. Villeneuve LM, Reddy MA, Lanting LL, Wang M, Meng L, and Natarajan R. Epigenetic histone H3 lysine 9 methylation in metabolic memory and inflammatory phenotype of vascular smooth muscle cells in diabetes. Proc Natl Acad Sci U S A 105: 9047-9052, 2008.

168. Vitale C, Mercuro G, Cornoldi A, Fini M, Volterrani M, and Rosano GM. Metformin improves endothelial function in patients with metabolic syndrome. $J$ Intern Med 258: 250-256, 2005.

169. Wang X, Zhu H, Snieder H, Su S, Munn D, Harshfield G, Maria BL, Dong Y, Treiber F, Gutin B, and Shi H. Obesity related methylation changes in DNA of peripheral blood leukocytes. BMC Med 8: 87, 2010.

170. Watanabe K, Watanabe R, Konii H, Shirai R, Sato K, Matsuyama TA, Ishibashi-Ueda H, Koba S, Kobayashi Y,
Hirano $\mathrm{T}$, and Watanabe $\mathrm{T}$. Counteractive effects of omentin-1 against atherogenesisdagger. Cardiovasc Res 110: 118-128, 2016.

171. Weber C, Shantsila E, Hristov M, Caligiuri G, Guzik T, Heine GH, Hoefer IE, Monaco C, Peter K, Rainger E, Siegbahn A, Steffens S, Wojta J, and Lip GY. Role and analysis of monocyte subsets in cardiovascular disease. Joint consensus document of the European Society of Cardiology (ESC) Working Groups "Atherosclerosis \& Vascular Biology" and "Thrombosis." Thromb Haemost 116: 626-637, 2016.

172. Wilk G, Osmenda G, Matusik P, Nowakowski D, Jasiewicz-Honkisz B, Ignacak A, Czesnikiewicz-Guzik M, and Guzik TJ. Endothelial function assessment in atherosclerosis: comparison of brachial artery flowmediated vasodilation and peripheral arterial tonometry. Pol Arch Med Wewn 123: 443-452, 2013.

173. Winer DA, Winer S, Shen L, Wadia PP, Yantha J, Paltser G, Tsui H, Wu P, Davidson MG, Alonso MN, Leong HX, Glassford A, Caimol M, Kenkel JA, Tedder TF, McLaughlin T, Miklos DB, Dosch HM, and Engleman EG. B cells promote insulin resistance through modulation of $\mathrm{T}$ cells and production of pathogenic IgG antibodies. Nat Med 17: 610-617, 2011.

174. Winer S, Chan Y, Paltser G, Truong D, Tsui H, Bahrami J, Dorfman R, Wang Y, Zielenski J, Mastronardi F, Maezawa Y, Drucker DJ, Engleman E, Winer D, and Dosch HM. Normalization of obesity-associated insulin resistance through immunotherapy. Nat Med 15: 921-929, 2009.

175. Winnik S, Auwerx J, Sinclair DA, and Matter CM. Protective effects of sirtuins in cardiovascular diseases: from bench to bedside. Eur Heart J 36: 3404-3412, 2015.

176. Wirth A, Wang S, Takefuji M, Tang C, Althoff TF, Schweda F, Wettschureck N, and Offermanns S. Agedependent blood pressure elevation is due to increased vascular smooth muscle tone mediated by G-protein signalling. Cardiovasc Res 109: 131-140, 2016.

177. Wu H, Ghosh S, Perrard XD, Feng L, Garcia GE, Perrard JL, Sweeney JF, Peterson LE, Chan L, Smith CW, and Ballantyne CM. T-cell accumulation and regulated on activation, normal $\mathrm{T}$ cell expressed and secreted upregulation in adipose tissue in obesity. Circulation 115: 10291038, 2007.

178. Xie H, Lim B, and Lodish HF. MicroRNAs induced during adipogenesis that accelerate fat cell development are downregulated in obesity. Diabetes 58: 1050-1057, 2009.

179. Xu X, Tan X, Tampe B, Nyamsuren G, Liu X, Maier LS, Sossalla S, Kalluri R, Zeisberg M, Hasenfuss G, and Zeisberg EM. Epigenetic balance of aberrant Rasal1 promoter methylation and hydroxymethylation regulates cardiac fibrosis. Cardiovasc Res 105: 279-291, 2015.

180. Yan M, Chen C, Gong W, Yin Z, Zhou L, Chaugai S, and Wang DW. miR-21-3p regulates cardiac hypertrophic response by targeting histone deacetylase-8. Cardiovasc Res 105: 340-352, 2015.

181. Yang X, Wang X, Liu D, Yu L, Xue B, and Shi H. Epigenetic regulation of macrophage polarization by DNA methyltransferase 3b. Mol Endocrinol 28: 565-574, 2014.

182. Yeung F, Hoberg JE, Ramsey CS, Keller MD, Jones DR, Frye RA, and Mayo MW. Modulation of NF-kappaBdependent transcription and cell survival by the SIRT1 deacetylase. EMBO J 23: 2369-2380, 2004. 
183. Youn JY, Siu KL, Lob HE, Itani H, Harrison DG, and Cai $\mathrm{H}$. Role of vascular oxidative stress in obesity and metabolic syndrome. Diabetes 63: 2344-2355, 2014.

184. Yu X, Zhang L, Wen G, Zhao H, Luong LA, Chen Q, Huang Y, Zhu J, Ye S, Xu Q, Wang W, and Xiao Q. Upregulated sirtuin 1 by miRNA-34a is required for smooth muscle cell differentiation from pluripotent stem cells. Cell Death Differ 22: 1170-1180, 2015.

185. Zampetaki A, Kiechl S, Drozdov I, Willeit P, Mayr U, Prokopi M, Mayr A, Weger S, Oberhollenzer F, Bonora E, Shah A, Willeit J, and Mayr M. Plasma microRNA profiling reveals loss of endothelial miR-126 and other microRNAs in type 2 diabetes. Circ Res 107: 810-817, 2010.

186. Zhang D, Hu X, Henning RH, and Brundel BJ. Keeping up the balance: role of HDACs in cardiac proteostasis and therapeutic implications for atrial fibrillation. Cardiovasc Res 109: 519-526, 2016.

187. Zhao J, Goldberg J, Bremner JD, and Vaccarino V. Global DNA methylation is associated with insulin resistance: a monozygotic twin study. Diabetes 61: 542-546, 2012.

188. Zheng Z, Chen H, Li J, Li T, Zheng B, Zheng Y, Jin H, He $\mathrm{Y}, \mathrm{Gu} \mathrm{Q}$, and $\mathrm{Xu} \mathrm{X}$. Sirtuin 1-mediated cellular metabolic memory of high glucose via the LKB1/AMPK/ROS pathway and therapeutic effects of metformin. Diabetes 61: 217-228, 2012.

189. Zhou S, Chen HZ, Wan YZ, Zhang QJ, Wei YS, Huang S, Liu JJ, Lu YB, Zhang ZQ, Yang RF, Zhang R, Cai H, Liu DP, and Liang CC. Repression of P66Shc expression by SIRT1 contributes to the prevention of hyperglycemiainduced endothelial dysfunction. Circ Res 109: 639-648, 2011.

190. Zhuge F, Ni Y, Nagashimada M, Nagata N, Xu L, Mukaida N, Kaneko S, and Ota T. DPP-4 inhibition by linagliptin attenuates obesity-related inflammation and insulin resistance by regulating M1/M2 macrophage polarization. Diabetes 65: 2966-2979, 2016.

Address correspondence to: Prof. Francesco Cosentino Cardiology Unit

Department of Medicine Karolinska Institute

Karolinska University Hospital Stockholm SE 17176

Sweden

E-mail: francesco.cosentino@ki.se

Date of first submission to ARS Central, August 23, 2017; date of acceptance, September 4, 2017.

\section{Abbreviations Used}

AGEs = advanced glycation end products

AMPK $=$ AMP-activated protein kinase

Ang II = angiotensin II

AP-1 $=$ activator protein-1

$\mathrm{ApoE}=$ apolipoprotein $\mathrm{E}$

$\mathrm{AT}=$ adipose tissue
$\mathrm{ATP}=$ adenosine triphosphate

$\mathrm{BBB}=$ blood/brain barrier

$\mathrm{CCL}=\mathrm{CC}$ chemokine ligand

$\mathrm{CREB}=$ cyclic $\mathrm{AMP}-$ response element-binding protein

$\mathrm{CVD}=$ cardiovascular disease

$\mathrm{CXCL}=\mathrm{C}-\mathrm{X}-\mathrm{C}$ motif chemokine

$\mathrm{EC}=$ endothelial cell

eNOS $=$ endothelial nitric oxide synthase

$\mathrm{FOXO}=$ forkhead transcription factor

$\mathrm{GH}=$ growth hormone

$\mathrm{H}_{2} \mathrm{O}_{2}=$ hydrogen peroxide

$\mathrm{HAT}=$ histone acetyltransferase

$\mathrm{HDAC}=$ histone deacetylase

HO- $1=$ heme oxygenase 1

IFN- $\gamma=$ interferon gamma

IGF-1 = insulin growth factor 1

$\mathrm{IgG}=$ immunoglobulin $\mathrm{G}$

$\mathrm{IL}=$ interleukin

iNOS $=$ inducible nitric oxide synthase

Ins $=$ insulin

IRAK1 $=$ interleukin 1 receptor-associated kinase 1

IRS $=$ insulin receptor substrate

$\mathrm{I} \kappa-\mathrm{B} \alpha=$ inhibitory subunit of nuclear factor-kappa B

$\mathrm{KLF}=$ kruppel-like factor

$\mathrm{M} 1 / \mathrm{M} 2=$ types of macrophages

MCP-1 = monocyte chemoattractant protein 1 $\mathrm{Mf}=$ macrophage

$\operatorname{miRNAs}=$ microRNAs

$\mathrm{Mo}=$ monocytes

$\mathrm{MR}=$ mineralocorticoid receptor

$\mathrm{mTOR}=$ mechanistic target of rapamycin

$\mathrm{NADPH}=$ nicotinamide adenine dinucleotide phosphate

$\mathrm{NFLD}=$ nonalcoholic fatty liver disease

$\mathrm{NF}-\kappa \mathrm{B}=$ nuclear factor kappa $\mathrm{B}$

$\mathrm{NO}=$ nitric oxide

NOR-1 = neuron-derived orphan receptor-1

Nox $=$ nonphagocytic NADPH oxidase

OXPHOS $=$ oxidative phosphorylation

$\mathrm{PAH}=$ pulmonary arterial hypertension

$\mathrm{PGI}_{2}=$ prostacyclin

$\mathrm{PKC}=$ protein kinase $\mathrm{C}$

PPAR $=$ peroxisome proliferator-activated receptor

PVAT $=$ perivascular adipose tissue

RANTES $=$ regulated on activation, normal $\mathrm{T}$ cell expressed and secreted

RCAN1 $=$ regulator of calcineurin 1

ROS $=$ reactive oxygen species

STAT $4=$ signal transducer and activator transcription 4 $\mathrm{T} 2 \mathrm{D}=$ type 2 diabetes

$\mathrm{Tb} 21=\mathrm{T}$ helper cell type 1 transcription factor

$\mathrm{TCA}=$ tricarboxylic acid

TLR4 $=$ toll-like receptor 4

$\mathrm{TNF} \alpha=$ tumor necrosis factor alpha

$\mathrm{TRAF}=\mathrm{TNF}$ receptor-associated factor

Treg $=\mathrm{T}$ regulatory cells

$\operatorname{Trp}=$ tryptophan

$\mathrm{VAT}=$ visceral adipose tissue

VCAM $=$ vascular cell adhesion molecule

$\mathrm{VSMC}=$ vascular smooth muscle cell

$\mathrm{WT}=$ wild type

$\mathrm{XO}=$ xanthine oxidase 